\title{
Vulnerability and Adaptation to Flood Hazards in Rural Settlements of Limpopo Province, South Africa
}

\author{
Rendani B. Munyai ${ }^{1,2}$, Hector Chikoore ${ }^{3} \mathbb{D}$, Agnes Musyoki ${ }^{2}$, James Chakwizira ${ }^{4}$, Tshimbiluni P. Muofhe ${ }^{5} \mathbb{D}$, \\ Nkosinathi G. Xulu ${ }^{6, *}$ and Tshilidzi C. Manyanya ${ }^{7}$ (D)
}

1 Department of Geography, University of South Africa, Florida 1709, South Africa; munyarb@unisa.ac.za

2 Department of Geography and Geo-Information Sciences, University of Venda, Thohoyandou 0950, South Africa; amusyoki1@gmail.com

3 Unit for Environmental Sciences and Management, North-West University, Vanderbijlpark 1900, South Africa; 32945280@nwu.ac.za

4 Department of Urban and Regional Planning, North-West University, Potchefstroom 2351, South Africa; 26878208@nwu.ac.za

5 Global Change Institute, University of the Witwatersrand, Johannesburg 2000, South Africa; 2385587@students.wits.ac.za

6 Department of Geography and Environmental Studies, University of Zululand, KwaDlangezwa 3886, South Africa

7 Division of Nature, Forest and Landscape, Katholieke Universiteit Leuven, 3000 Leuven, Belgium; tshilidzicloudia.manyanya@student.kuleuven.be

* Correspondence: xulung@unizulu.ac.za; Tel.: +27-035-902-6331

Citation: Munyai, R.B.; Chikoore, H.; Musyoki, A.; Chakwizira, J.;

Muofhe, T.P.; Xulu, N.G.;

Manyanya, T.C. Vulnerability and Adaptation to Flood Hazards in Rural Settlements of Limpopo Province, South Africa. Water 2021, 13, 3490. https://doi.org/10.3390/w13243490

Academic Editor: Piotr Matczak

Received: 22 September 2021

Accepted: 30 November 2021

Published: 7 December 2021

Publisher's Note: MDPI stays neutral with regard to jurisdictional claims in published maps and institutional affiliations.

Copyright: (c) 2021 by the authors. Licensee MDPI, Basel, Switzerland. This article is an open access article distributed under the terms and conditions of the Creative Commons Attribution (CC BY) license (https:/ / creativecommons.org/licenses/by/ $4.0 /)$.
Abstract: Climate change has increased the frequency of extreme weather events such as heavy rainfall leading to floods in several regions. In Africa, rural communities are more vulnerable to flooding, particularly those that dwell in low altitude areas or near rivers and those regions affected by tropical storms. This study examined flood vulnerability in three rural villages in South Africa's northern Limpopo Province and how communities are building resilience and coping with the hazard. These villages lie at the foot of the north-eastern escarpment, and are often exposed to frequent rainfall enhanced by orographic factors. Although extreme rainfall events are rare in the study area, we analyzed daily rainfall and showed how heavy rainfall of short duration can lead to flooding using case studies. Historical floods were also mapped using remote sensing via the topographical approach and two types of flooding were identified, i.e., those due to extreme rainfall and those due to poor drainage or blocked drainage channels. A field survey was also conducted using questionnaires administered to samples of affected households to identify flood vulnerability indicators and adaptation strategies. Key informant interviews were held with disaster management authorities to provide additional information on flood indicators. Subsequently, a flood vulnerability index was computed to measure the extent of flood vulnerability of the selected communities and it was found that all three villages have a 'vulnerability to floods' level, considered a medium level vulnerability. The study also details temporary and long-term adaptation strategies/actions employed by respondents and interventions by local authorities to mitigate the impacts of flooding. Adaptation strategies range from digging furrows to divert water and temporary relocations, to constructing a raised patio around the house. Key recommendations include the need for public awareness; implementation of a raft of improvements and a sustainable infrastructure maintenance regime; integration of modern mitigations with local indigenous knowledge; and development of programs to ensure resilience through incorporation of Integrated Development Planning.

Keywords: flood risk; exposure; susceptibility; resilience; flood vulnerability index; adaptation

\section{Introduction}

Floods are characterized as some of the most severe, dangerous and harmful natural hazards [1] causing loss of lives and livelihoods, disrupting socio-economic activities and damaging infrastructure. Floods may result from high run-off or a rise in water levels 
in a particular area that is more than what that environment can contain [2,3], and are regular and recurring risks to society [4]. They cause more economic losses in the world than any other natural hazard and are a major risk to Gross Domestic Product (GDP) [5]. Economic costs result not only from damages to infrastructure and property, but also include disaster relief efforts towards individuals and businesses. Some floods may also be compounded by poor drainage and culvert designs, poor siting, location of settlements and topographic forces, which are key determinants of vulnerability. Despite these factors, one of the immediate causes of flooding is the occurrence of extreme/intense rainfall in a short duration. Rainfall intensity, volume, timing, and antecedent conditions of rivers and their drainage basins, in addition to human encroachment into flood plains and lack of flood response plans increase the damage potential [6].

There is evidence that the numbers of people affected and economic damages due to flooding are rising at alarming rates $[7,8]$. This rise is exacerbated by global climate change, as severe storms associated with strong winds and flooding have become more frequent. Climate change has caused greater variability in precipitation patterns, increased intensification and frequent occurrences of natural hazards [9], increasing the risk of flooding in several regions. Floods are very contextual, suggesting that their impacts and social vulnerability depend on specific circumstances [10] and may vary from region to region, usually being more severe in developing communities [11]. This contextually emphasizes the great need for flood risk vulnerability assessments at all spatial scales.

South Africa is exposed and susceptible to flood hazards and the most vulnerable provinces are the Eastern Cape, Kwa-Zulu Natal, the North-West and Limpopo which are largely rural [12]. Zuma et al. [13] calculated the risk of flooding in South Africa and found an $83.3 \%$ chance of floods occurring in a given year. They also determined that levels of vulnerability are generally high mainly due to socio-economic and geographical factors. It has been found that rural settlements and infrastructure located in valleys and wetlands are more vulnerable to flood risks and disasters [3]. The effects of population growth, settlement developments and expansion of the rural-urban hinterland have also worsened the magnitude and frequency of flooding or ponding. Poor rural communities are more exposed and have become susceptible or sensitive to flood hazards. In some rural areas of South Africa, flood events disrupt transportation on gravel roads with downstream effects on several socio-economic activities [14].

We focus on the country's northern Limpopo province which receives most rainfall during the austral summer months $[15,16]$, but for which the rainy season may extend from October to April. The main source of rainfall during this period is associated with moisture flux inflow mainly from the warm southwest Indian Ocean [17]. Most of the extreme rainfall events over the region are attributed to rain-bearing weather systems such as cloud bands, tropical lows, mesoscale convective complexes and cut-off lows [16]. Cloud bands form along tropical-temperate troughs (TTTs) that extend from the tropics to the mid-latitudes and produce nearly half of the seasonal rainfall over the summer rainfall region of South Africa [18]. Slow moving cloud bands can dump heavy rainfall as they propagate eastwards through Limpopo towards Madagascar via the Mozambique Channel. The occasional landfall of tropical cyclones (identified as tropical lows over land) over southern Mozambique during the late summer is also linked to heavy rainfall and flooding in the province.

Floods due to ex-tropical cyclone Eline in 2000 and continental tropical lows in 2011, 2013 and 2014 have raised various concerns regarding flood vulnerability and preparedness in South Africa's north-eastern interior. A more recent flood event occurred in Thohoyandou, northeast of South Africa during February 2019 after extreme precipitation $(\sim 300 \mathrm{~mm} / 4 \mathrm{~h})$ associated with a major cloud band [15]. A nearby shopping mall was inundated with flood waters such that some vehicles were stagnated, raising concerns of poor siting and drainage. It was found that the interaction of a low-level jet with a nearby mountain range compounded the heavy rainfall and flooding in the area [15]. Thus, this region is highly vulnerable to flooding from extreme rainfall, which may be exacerbated 
by climate change. It is also in the Limpopo Province that climate change models project a strong signal of warming in the future climate, e.g., $[19,20]$. The latest projections from the Intergovernmental Panel on Climate Change (IPCC) Assessment Report Six suggest (with high confidence) increased frequency of heavy precipitation over South Africa in future [20].

From season to season, the climate of South Africa's Limpopo Province is also influenced by remote phenomena from hot spots in the Indian and Pacific Oceans. The El Niño Southern Oscillation (ENSO) is a dominant phenomenon that regulates the occurrence of extreme events such as droughts, heat waves and floods in the region [17,21]. El Niño events over the equatorial Pacific Ocean are mostly linked to dry and hot austral summers over the northeastern interior of the country [22-24]. During this time, fewer cloud bands form, leading to below normal rainfall over the southern African subcontinent [15]. The circulation becomes largely anticyclonic characterized by subsidence induced a strong mid-troposheric Botswana High [25]. In contrast, most La Niña events have been linked to positive rainfall anomalies in the region [26], with enhanced moisture flux from the southwest Indian Ocean. Hence, the risk of flooding is enhanced during La Niña events in the northeast of South Africa. The occurrence of La Niña has also been linked to high/extreme streamflow events in several other regions in the tropics [27-29], which increase the risk of riverine flooding. Due to its warm climate, the Limpopo Province is also vulnerable to climate-sensitive diseases such as malaria, which often peak after a flood event. After floods, ponds create conducive conditions for breeding of Anopheles arabiensis mosquitoes, which are the common species transmitting malaria in the area [30,31]. Cholera outbreaks also occur in Limpopo following flood events as many rural communities do not have piped/reticulated water supply. Thus, flood events also put human health, lives and livelihoods at risk, as water-borne and vector-borne diseases become more likely. Tourism is a major economic activity in the province due to large areas of wildlife/game parks, including the renowned Kruger National Park and the Mapungubwe National Park. When floods occur, huge economic losses are incurred by the tourism sector mainly due to damage to infrastructure [32].

As a consequence of the vulnerability of the Limpopo Province to weather and climate extremes, several studies have detailed flood vulnerabilities, water pollution, impacts and adaptation in the province, e.g., [3,32-36]. However, the majority of the literature has focused on the Luvuvhu River Catchment, which is a major sub-catchment of the Limpopo River. This study focuses on flood vulnerabilities in Mopani, a district of the Limpopo Province which has not received adequate research attention.

Although studies have tackled floods from various fields and perspectives in the region, a paucity of vulnerability assessments for rural settlements to flood hazards remains. Several local communities have been declared vulnerable to floods, but little is known about the extent of their vulnerability. Our study of floods in rural South Africa is motivated by these vulnerabilities. Several indices have been developed to assess/measure levels of flood vulnerability at different spatial scales towards flood hazard management [37]. The more recent approaches have focused on geospatial techniques for vulnerability assessment [37]. Several studies have defined vulnerability as a measure of potential harm to communities caused by a natural hazard, e.g., [38-41]. A number of quantitative flood vulnerability indices have been developed to investigate the extent of potential harm due to exposure, susceptibility and resilience [42-46]. Tools and indicators have been documented linking theoretical concepts to strategy development, policies, decision making and adaptation $[9,42]$ with all having unique and various responses to flood occurrences. This has been crucial for characterizing vulnerability indices and indicators relative to regions and focusing on physical, economic and social vulnerability [47]. Our study combines analysis of rainfall extremes, remote sensing and geo-spatial techniques with a vulnerability assessment using a Flood Vulnerability Index (FVI) developed and detailed in Balica et al. [42] and Balica and Wright [48]. The FVI calculates a single number based on social, economic, environmental and physical components in the water resource system [42]. 
Thus, the main aim of this study is to (a) assess the nature and extent of flood vulnerability and (b) establish adaptation strategies employed by three selected rural communities in Mopani District Municipality affected by the flood hazard repeatedly in recent years. The remainder of the paper is structured as follows: a study area description precedes the data and methods section, and the results are presented as subsections. A discussion and recommendations for flood management are offered at the end.

\section{Materials and Methods}

\subsection{Study Area}

Although this study deals with South Africa's northeastern Limpopo Province, it mainly focused on rural communities in the wetter western region of Mopani District Municipality (Figures 1 and 2) which are vulnerable to various natural hazards including floods, droughts and heat waves. The proximity of the study area to the warm South Indian Ocean (Figure 1) makes it vulnerable to tropical cyclones that reach land during the late austral summer $[49,50]$. The lowveld in the northeast is separated from the interior plateau by an escarpment, and our study sites lie in this transition zone, where rainfall is enhanced by orographic factors. The study focused on communities in Lenyenye, Nkowankowa Section B and C (in Greater Tzaneen Municipality) and Ga-Kgapane Masakaneng in Greater Letaba Municipality (Figure 2) which are largely semi-rural, while also providing labor to the eucalyptus and citrus plantations and urban areas of Greater Tzaneen.

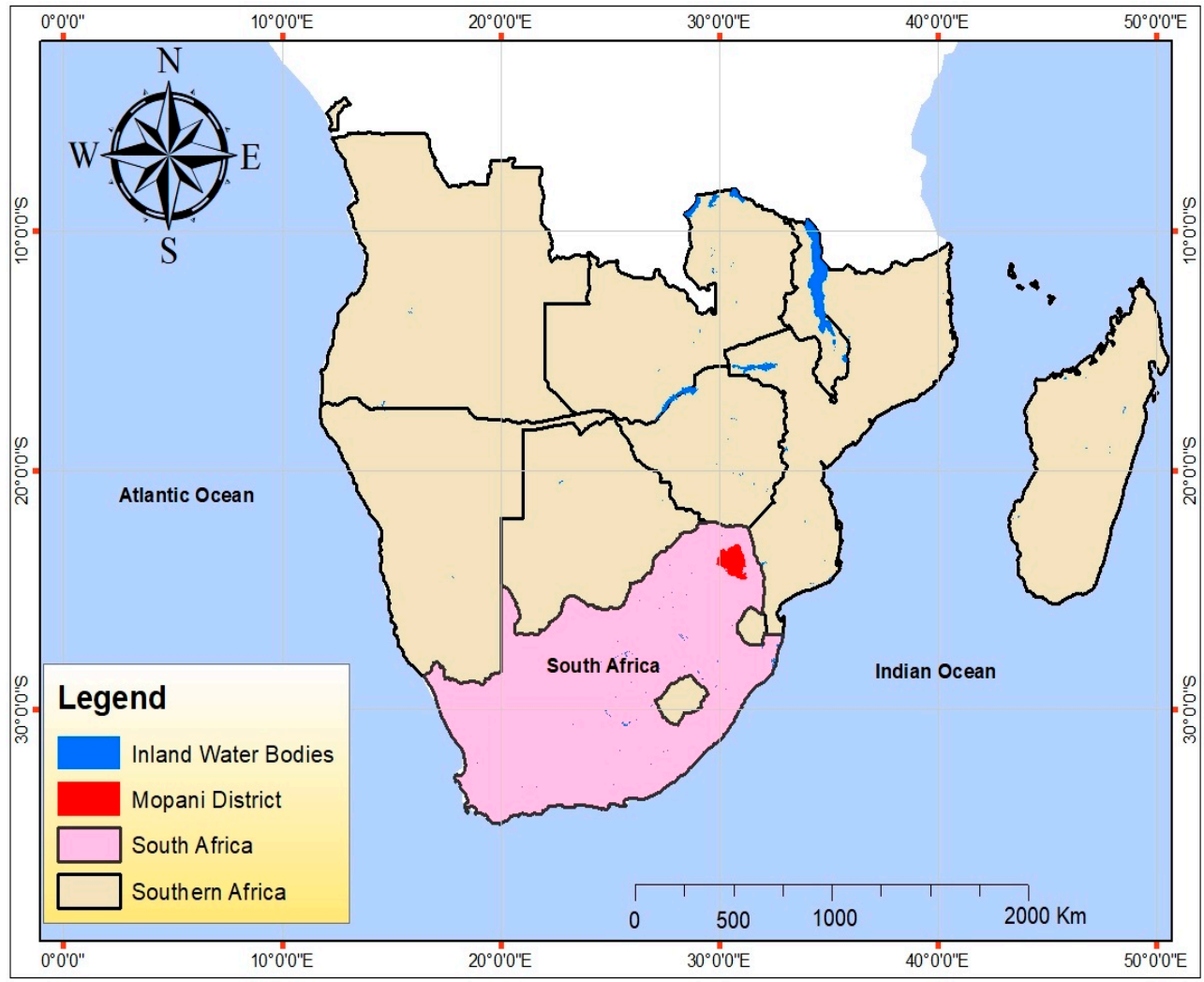

Figure 1. Location of Mopani District Municipality in the southern Africa region, northeast of South Africa. The district is in close proximity of the warm Indian Ocean in the east. 


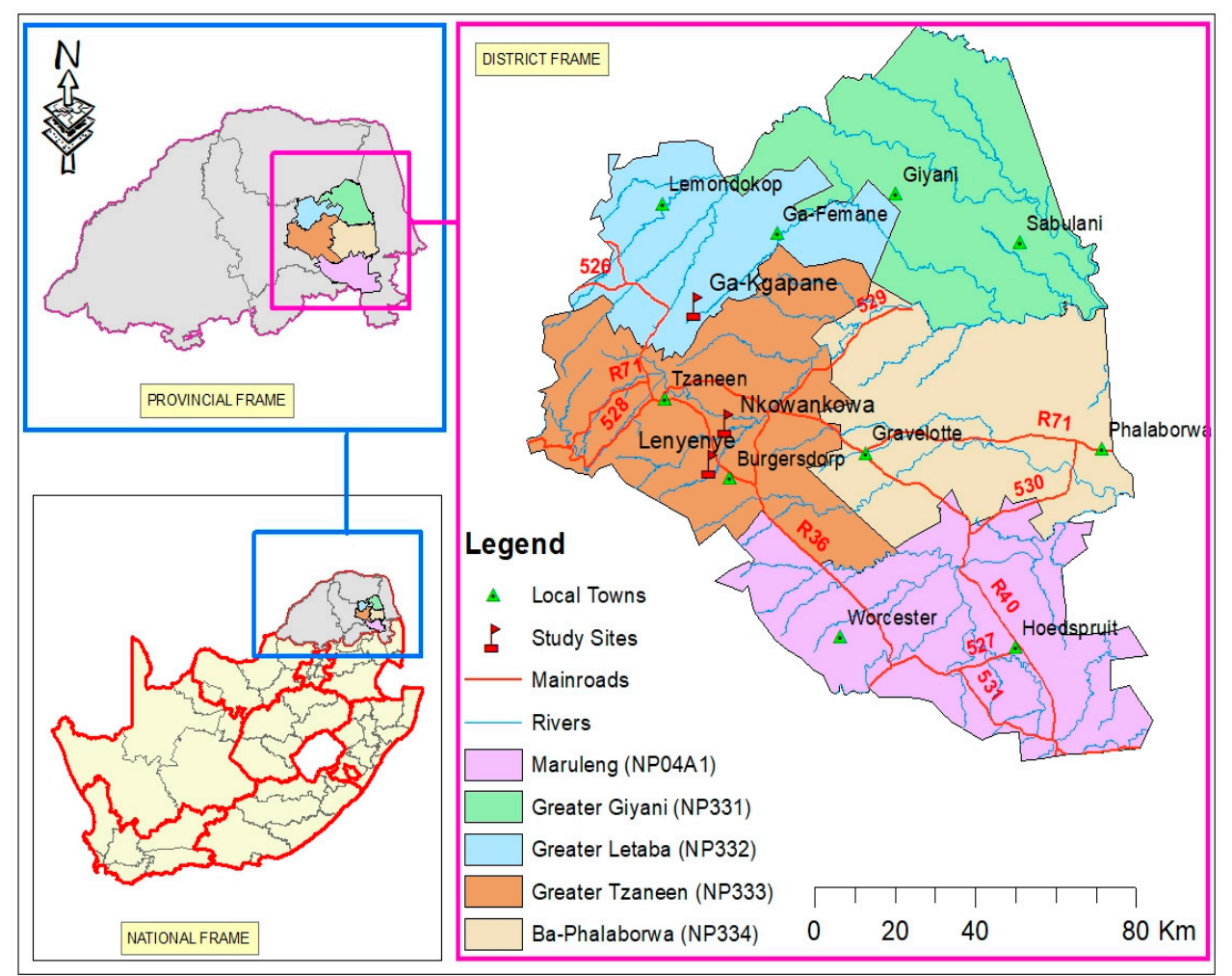

Figure 2. South Africa (national frame): Location of the three study sites (in red flags) in Mopani District's Greater Tzaneen and Greater Letaba municipalities.

The Mopani District Municipality in South Africa's Limpopo Province is made up of Maruleng, Greater Giyani, Greater Tzaneen, Greater Letaba and Ba-Phalaborwa local municipalities (Figure 2), which are variously exposed and vulnerable to flood hazards. Major flood events have occurred in Mopani during the past decade. In 2012, a total of 662 households were affected by floods, with Molalane village (east of the district, Maruleng Municipality) being the hardest hit [51]. However, it has been found that the most affected rural settlements in the Mopani District are Lenyenye, Ga-Kgapane and Nkowankowa Section B and C. These communities have been seriously exposed because they are located near rivers, while also being susceptible to high rainfall due to the proximity of the escarpment. The generally flat terrain and poor drainage in Nkowankowa Section B and $C$ promote ponding to occur readily after a rainy day (Figure 3 ). The generally low socio-economic status of households has compounded the susceptibility of these rural communities to the natural hazard. 


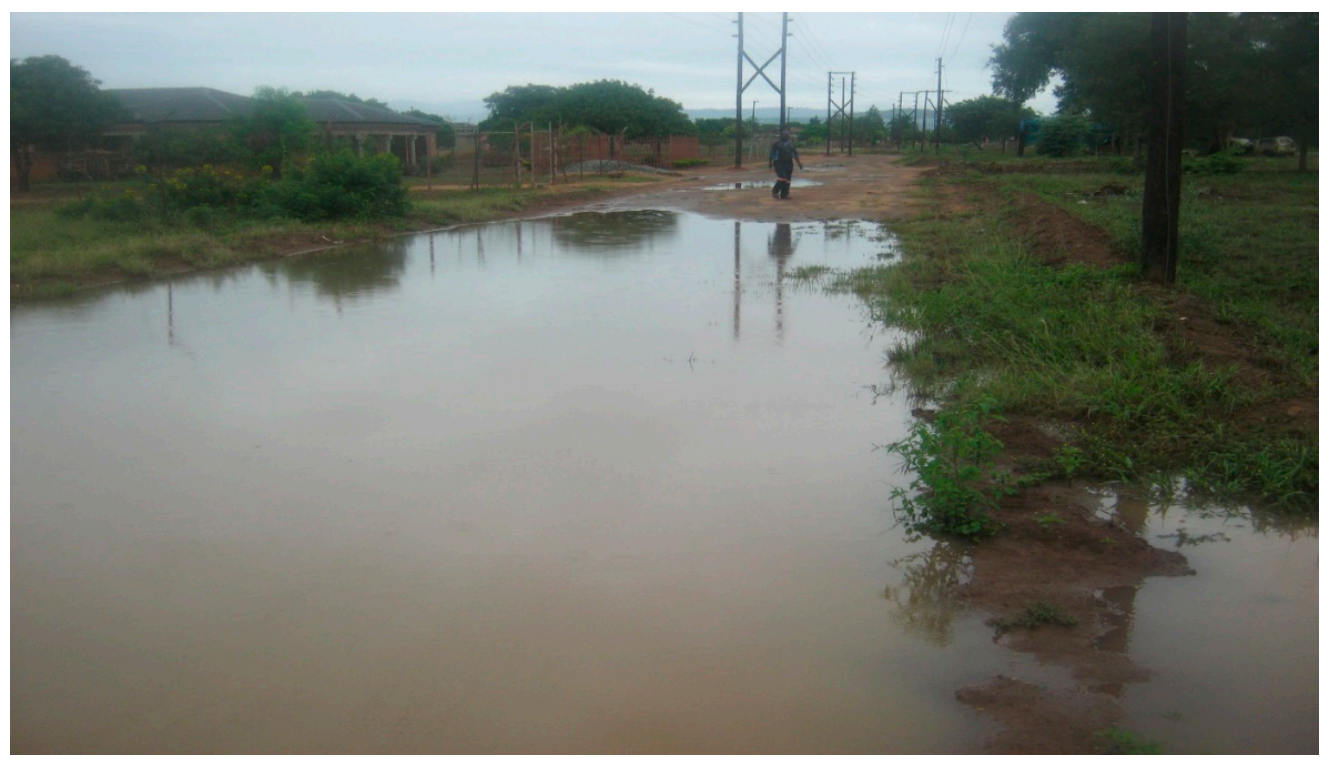

Figure 3. A flooded street in Nkowankowa, Greater Tzaneen Municipality due to both topography and poor drainage and culvert design [source: Field survey, 2016].

\subsection{Data and Methods}

This study was conducted using a mixed-method approach, mainly on a quantitative survey research design and supplemented by a qualitative survey. Quantitative data collection included an analysis of the occurrence of extreme rainfall and flooding using remote sensed data and also from questionnaires administered in the three study sites and target households.

As a background to the vulnerability analysis, we present a climatology of daily rainfall in the study area and analyze case studies of extreme rainfall which led to flood events. To identify and map flood events, high resolution rainfall data was analyzed in this study. We employed the Climate Hazards Infrared Precipitation with Stations (CHIRPS), [52] data for the recent period from 2000 to 2020. The CHIRPS data are obtained at very high temporal (daily) and spatial resolution $\left(0.05^{\circ} \times 0.05^{\circ}\right)$ and derived from satellite infrared estimates and rain gauge observations [52]. The daily data are suitable for analysis of extreme events that may lead to floods. We also analyze the relationship between sea-surface temperature (SST) anomalies of the Niño 3.4 region (equatorial Pacific Ocean) and seasonal rainfall in the study region via correlation analysis.

The aerial extent and types of flood were mapped using geospatial and remote sensing data via the topographical approach to historical flood mapping. This is a process that analyzes the structure of the top layer of the Earth's surface to determine the areas that are prone to flooding and also provides a topographical explanation of historically recorded floods. The method for topographical drainage channel analysis involves an initial step which is to map the natural topographical drainage channels. This was undertaken using data from the Shuttle Radar topography mission (SRTM), which is accessible from NASA's database at $30 \mathrm{~m}$ resolution. This data is used to create a digital elevation model (DEM), which is the basis for this analysis. Using the ArcMap Hydrological tools toolbox, the DEM is filled for sinks and analyzed for flow direction from each cell using the D8 algorithm. This determines the direction in which water flows from every cell based on the proven motion of water that it always flows from a point of high elevation to a point of low elevation [53]. From the flow direction, the drainage basins are then clearly distinguished using the Basin Tool, after which the flow directions of each basis are analyzed for areas of greatest flow accumulation, into which most cells pour. For this study, the minimum number of cells pouring into a single cell was established to be 5000 because the interest was not only in perennial streams but also non-perennial runoff channels that only have water during 
rainfall events, as shown in Figure 4. The cell number threshold varies depending on the channel level as seen by Liu [54] and Theofanous [55], among others.

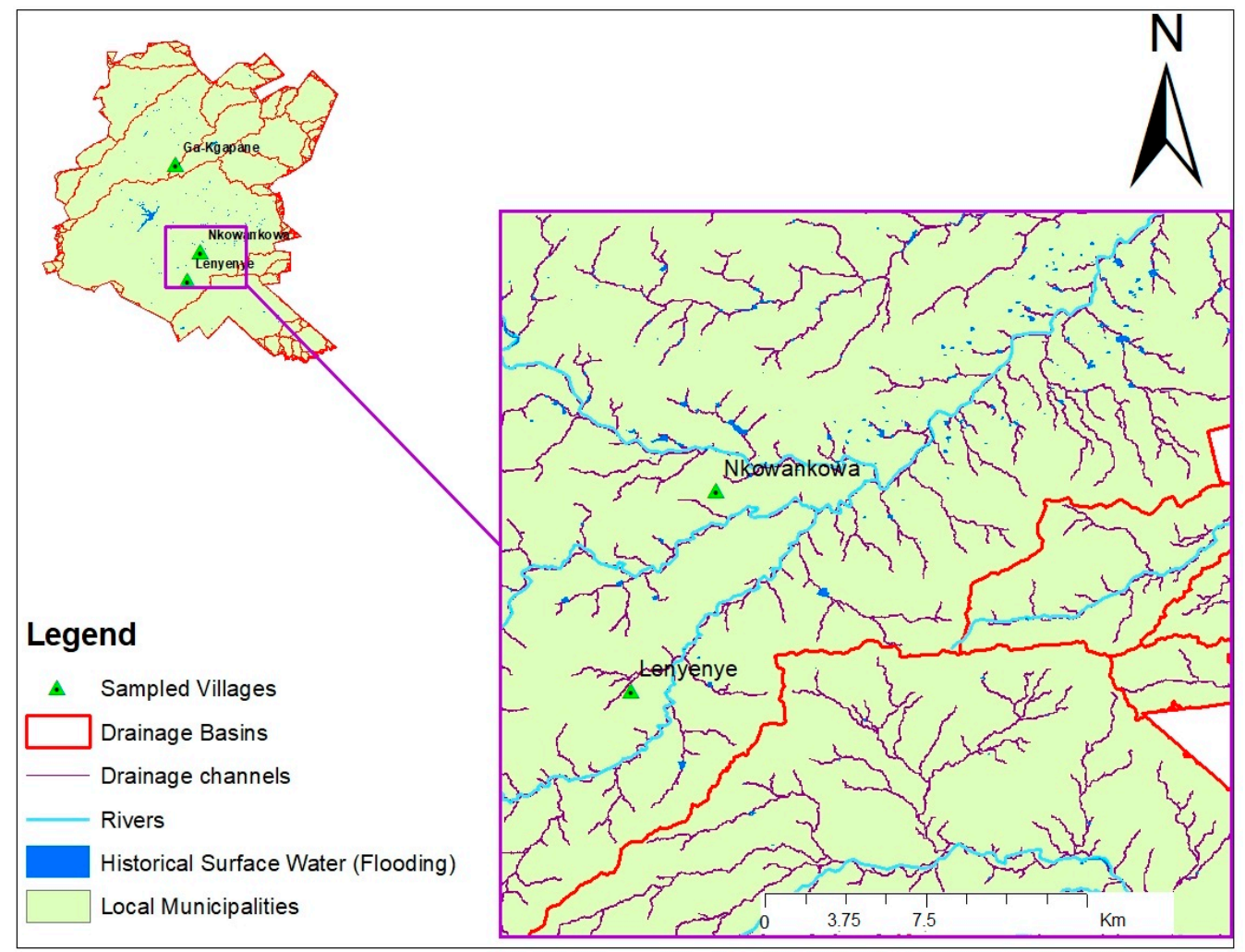

Figure 4. Study area flood locality map showing previously flooded areas relative to perennial rivers and drainage channels.

A limitation in satellite data when applied to flooding is a result of the fixed sensor temporal resolutions and revisit times, in addition to interference from upper atmospheric conditions [56]. Optical sensors cannot penetrate through clouds which are present during flooding events, creating a blind spot and, by the time the satellite revisits the same area in a few days, the flooding may be over or abated [56]. For most of the flooding dates observed in this study, there were no direct data due to these limitations. However, radar data provided a useful alternative because of its ability to penetrate through clouds, although the spatial resolution of Synthetic Aperture Radar (SAR) is at least $145 \mathrm{~km}$ [57]. Historical SAR-based surface water accumulation zones data were downloaded from the Copernicus hub and overlaid on top of the drainage channels on an aerial photograph of the study area for more visibility. The perennial rivers were also added and, interestingly, this revealed two distinct cases of flooding in the area.

In addition, qualitative data was provided by key informant interviews and focus group discussions using instruments mainly composed of semi-structured questions on indicators of vulnerability and the participation of authorities to mitigate flood impacts. Questionnaires were also distributed to target households to identify indicators and the extent of flood vulnerability. The questions included exposure, susceptibility and resilience indicators, and adaptation strategies/actions during floods (see Appendix A). The target households were sampled using the systematic random sampling method, a statistical method that is widely used in the social sciences research that employs a selection of components within an ordered sampling frame. The three settlements in Mopani District had total numbers of households as follows: Nkowankowa Section B and C-1860; Lenyenye-980; and Ga-Kgapane Masakaneng-706 [58]. Equivalently, 50\% of the total households (which is the unit of analysis in each community) were systematically sampled 
in a quantitative order of one in every 20 households. The households' sample sizes were calculated as follows:

$$
\text { Lenyenye }=\frac{\text { Total number of households }}{100} \times 50,
$$

Systematic sample of every 1 in 20th of the 490 households $=25$

$$
\text { Nkowankowa C, B }=\frac{\text { Total number of households }}{100} \times 50
$$

Systematic sample of every 1 in 20th of the 930 households $=47$

$$
\text { Ga-Kgapane }=\frac{\text { Total number of households }}{100} \times 50
$$

Systematic sample of every 1 in 20th of the 353 households $=18$.

Total number of questionnaires $=25+47+18=90$.

It was decided to raise the number of questionnaires to 100 such that Nkowankowa received three extra questionnaires and Ga-Kgapane Masakaneng was allocated seven additional questionnaires to make a total of 100 . With a sample size of 100 from a population of 1773 , the margin of error of $7.99 \%$ was computed using the Raosoft sample size calculator (http:/ / www.raosoft.com/samplesize.html, accessed on 15 November 2021).

Key informant interviews were conducted with a 'Risk Assessment Manager' of Mopani District Disaster Management Centre and two 'Storm Water Managers' of Nkowankowa Section B and C, Lenyenye and Ga-Kgapane Masakaneng. The informants were selected using the purposive sampling technique. This is a non-probability sampling method where investigated and selected units from a population are based on the subjective judgement of the researcher(s) [59]. Key informant interviews also included aspects of municipal adaptation strategies, information about indicators and flood impacts. To compute the FVI, both primary and secondary data sources were used in this study. Primary data were acquired through a quantitative questionnaire, a qualitative key informant interviews, and field observations; whereas secondary data were collected through Census, 2011 [60], South African Weather Service (SAWS) records and maps. The Mopani District Disaster Management Centre (MDDMC) was helpful in providing the majority of records, maps and information about relevant indicators for the FVI.

Questionnaire data from household surveys were analyzed through Microsoft Excel 2010 and Statistical Package for Social Sciences (SPSS) 23 spreadsheets. These data were coded and arranged, entered into Microsoft Excel 2010, and converted to SPSS 23 to create descriptive statistics. The entered data were summarized into percentages and frequencies, and key informant interviews' responses were analyzed using content analysis and arranged into themes. The themes and other responses were then grouped into identical categories, classified and synthesized, and the descriptive narrative technique was employed to discuss the results of key informant interviews.

The information collected from interviews, field observations, Statistics South Africa, SAWS observations and records were imputed into the FVI. The FVI is a parametric approach which is suitable to evaluate vulnerability to floods because it incorporates socio-economic and physical environment components. This index was used to measure the extent of flood vulnerability in the three study communities. Exposure, susceptibility and resilience are the three main factors of FVI, aligned with the social, economic and physical environment to reveal relevant indicators. Indicators were selected through a deductive approach and supported also by a preliminary survey for the relevancy of each indicator. Selected indicators were thoroughly reviewed and merged to be relevant in the three communities.

Exposure, susceptibility and resilience have different impacts on vulnerability. Resilience influences vulnerability negatively, whereas susceptibility and exposure positively influence vulnerability [61]. Exposure is a measure of predisposition to flooding due to the 
location; susceptibility measures the extent of exposure which may be related to awareness/preparedness; and resilience measures coping and recovery capacity during and after floods [48]. The general formula for FVI calculation uses categorization of the components into three groups of resilience, susceptibility and exposure indicators [47]. The formula used to calculate the FVI developed by Balica et al. Ref. [42] is:

$$
F V I=\frac{E \times S}{R} \text { or } F V I=(E+S)-R
$$

where $E$-exposure, $S$-susceptibility and $R$-resilience

FVI is equal to the sum of exposure and susceptibility minus resilience. The index gives a number on a scale from 0 to 1 , signifying low to high flood vulnerability respectively. FVI values greater than 0.5 are considered high vulnerability with very high vulnerability values from 0.75 to 1 [47]. FVI values lower than 0.25 are considered as small vulnerability to floods where recovery can be fast either due to high resilience or low economic development [47]. Interpretation of the FVI and descriptions of index value [47].

A high level of vulnerability to floods implies a high possibility of loss in any components $[47,62,63]$. The losses can be in a form of property, human lives, livelihoods, environment and others. High vulnerability to floods or other hazards has the potential to lead to catastrophes or natural disasters, especially in resource poor marginal regions of Africa. Normally, a very high vulnerability to flood is assigned to a system or circumstance in which there is a high probability of loss of life, whereas average vulnerability is assigned where there is a medium probability of harm to assets and lives of people. If a system or community is exposed to a small probability of harm and damage to the socio-economy and physical environment, a small vulnerability can be assigned. A "very small vulnerability to floods" is mostly related to a very small potential for damage to any system [47]. "Small vulnerability to floods" is normally due to the strong resilience of a specific community or system. Although a community may be exposed and susceptible to floods, the strongest determinant of vulnerability is its resilience capacity. Locations/households that are characterized by small vulnerability to a hazard mostly have a high resilience capacity [64].

\section{Results}

\subsection{The Occurrence of Extreme Rainfall}

Rainfall over the study area is strongly seasonal, occurring mainly during the austral summer months from December to February (Figure 5), although the entire rainfall season can span from October to April. Most rainfall over the study area is produced by cloud bands, connecting the Inter-Tropical Convergence Zone (northwestern end) to a cold front at its southeastern end. The rainfall here is also enhanced by the presence of a sharp topographic gradient (due to the north-eastern escarpment) such that the lowlands are more vulnerable. The annual cycle of daily rain shows that mean daily rainfall in the study area is below $10 \mathrm{~mm} /$ day (Figure 5; red line) which may be considered moderate. Although the occurrence of extreme rainfall is rare in this area [15], it is mostly linked to tropical continental lows and landfall of tropical cyclones from the warm Mozambique Channel and Southwest Indian Ocean [16]. It is also shown that the monthly mean for daily rainfall extremes can reach and exceed $50 \mathrm{~mm}$ /day during January and February (Figure 5; 97.5\% percentile, green line). 


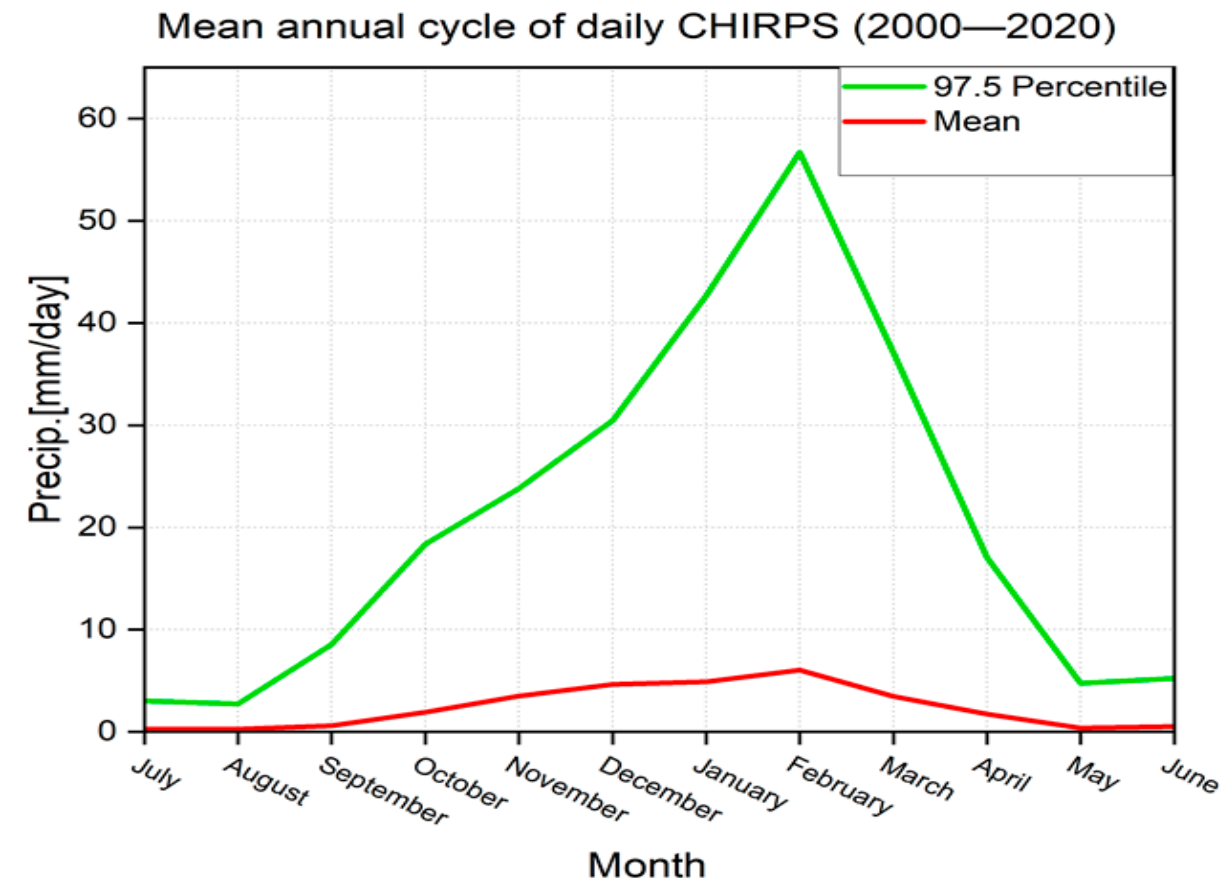

Figure 5. The mean annual cycle of daily CHIRPS rainfall over the study area (mm/day). The mean is shown in red and the $97.5 \%$ percentile is shown in green.

At inter-annual time scales, we show here that the study region has experienced heavy daily rainfall events several times during the past 21 years (2000-2020), which may be increasing in frequency due to climate change (Figure 6). In southern Africa, one definition of heavy rainfall events is when $24 \mathrm{~h}$ (daily) amounts exceed $50 \mathrm{~mm}$ [15]. The time-series in Figure 6 shows several distinct peaks with extreme amounts exceeding $100 \mathrm{~mm} /$ day during 2017 and 2018. Such events would most likely lead to ponding or flooding depending on other vulnerability factors such as drainage and terrain. It is also projected that sub-daily extreme rainfall events in southern Africa will become more frequent in the future [20,65], suggesting a corresponding increase in ponding, flash floods and fluvial flooding. These projections may imply increased future vulnerabilities in some areas.

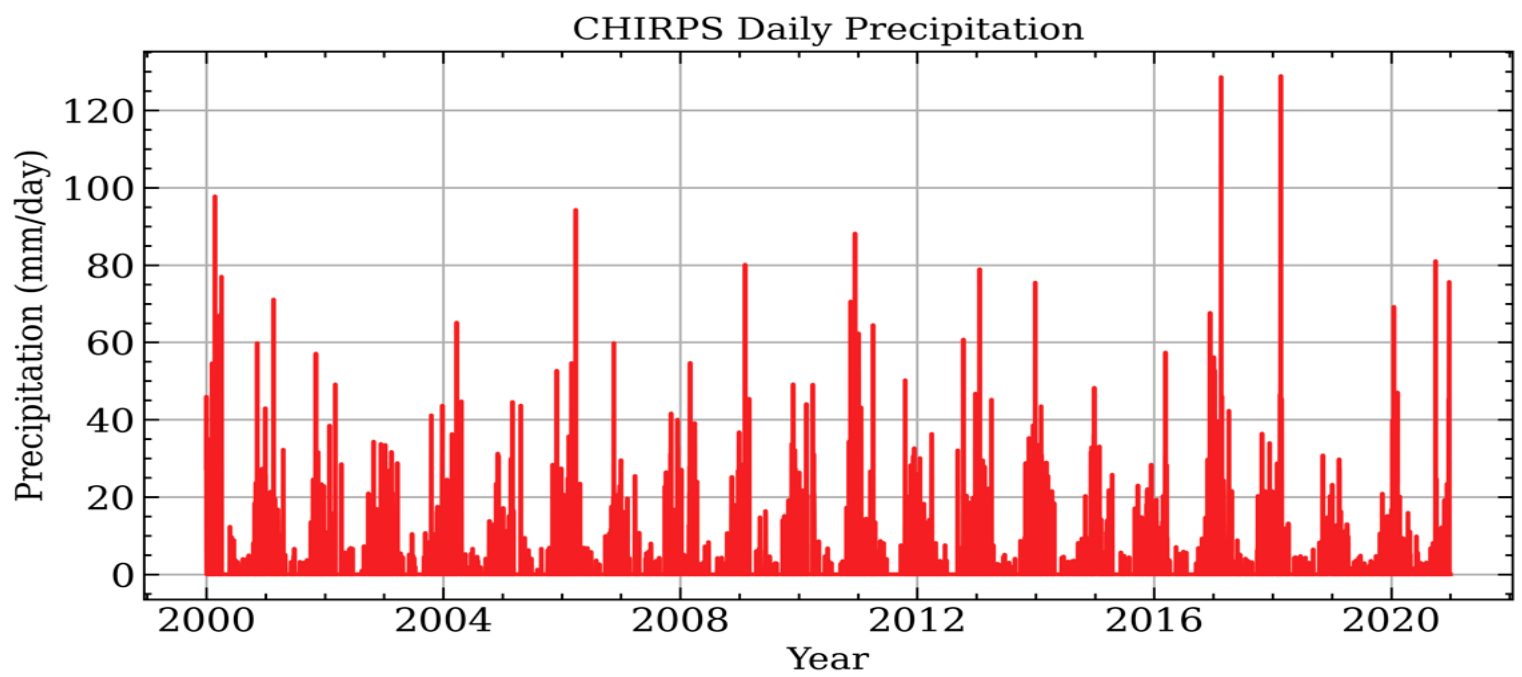

Figure 6. Inter-annual variability of CHIRPS daily precipitation over the Greater Tzaneen municipal area over the period from January 2000 to December 2020. 
We also analyzed the link between the occurrence of extreme rainfall and the ENSO phenomenon and found a statistically significant $(p<90 \%)$ relationship between SST anomalies over the equatorial Pacific Ocean and seasonal rainfall in the study area (Figure 7). El Niño events (positive Niño 3.4 SST) are mostly linked to drought and heat waves in Limpopo. The recent 2015/2016 El Niño, which is the most intense event, led to one of the most severe droughts that is comparable only to 1991/1992 and 1982/1983 (Figure 7; 17). Conversely, the heavy rainfall events that led to flooding in Mopani District during the 2012/2013 and 2013/2014 summers coincided with near-neutral weak La Niña events (Figure 7). However, although a statistically significant and negative correlation $(R=-0.436$; Figure 7$)$ exists between Nino 3.4 SST anomalies and extreme rainfall in the area, the relationship is partial, suggesting a more complex climatic regime. This suggests that above normal rainfall in the region is more likely during La Niña, implying a link with flood events.

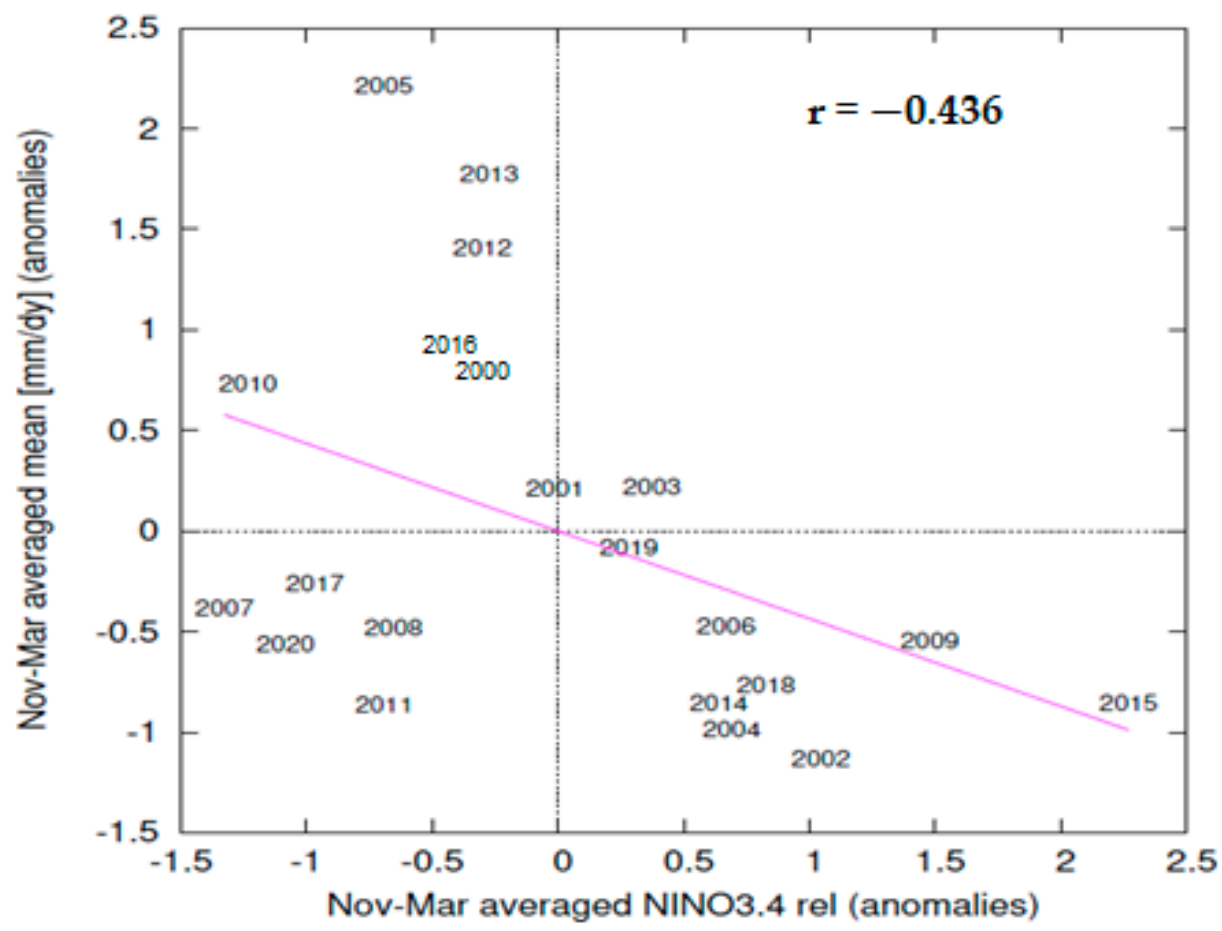

Figure 7. Correlation of Nino 3.4 SST anomalies with rainfall anomalies in the study area.

Several heavy rainfall events (exceeding $50 \mathrm{~mm} /$ day) that affected the area can be identified in 2000, 2006, 2007, 2011, 2013, 2014, 2017, 2018 and 2020, mostly in February (Figure 6). We focus on two of the more extreme events to show how intense rainfall affected the area and led to flooding: 20 January 2013 and 18 January 2020. It is shown that in both events, extreme rainfall amounts exceeding $100 \mathrm{~mm} /$ day were recorded in areas along the escarpment (Figure 8). Regarding the two events, although the general pattern is one of widespread precipitation across the province, there is a distinct west-east axis of extreme rainfall which shows the influence of orographic lifting in the northeastern escarpment in the study area (Figure 8).

The rainfall shown in Figure 8a was due to the influence of a tropical continental low-pressure system that developed and affected Mozambique, Zimbabwe, Botswana and South Africa. The slow movement of that tropical low coupled with a long life, which spanned the period 15-21 January 2013, resulted in extreme rainfall over the region. Several large areas of the Mopani District Municipality experienced floods, including the Kruger National Park, resulting in loss of lives and livelihoods [66]. The evolution of this weather system over the subcontinent in January 2013 and its impacts in Mopani District have been detailed in Webster [67]. 
CHIRPS Rainfall : 20 January 2013

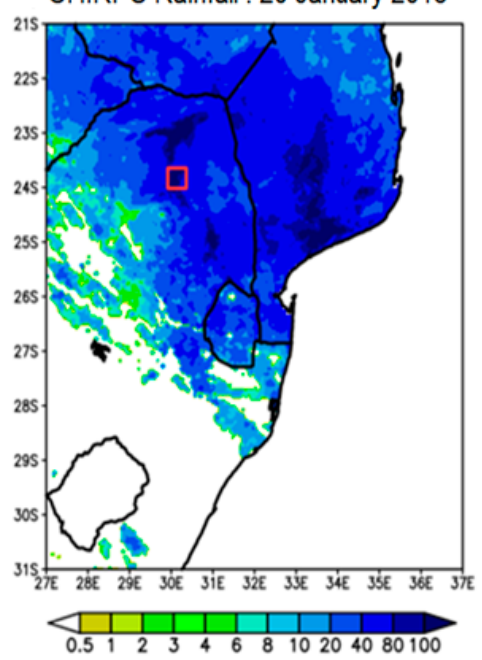

(a)
CHIRPS Rainfall : 18 January 2020

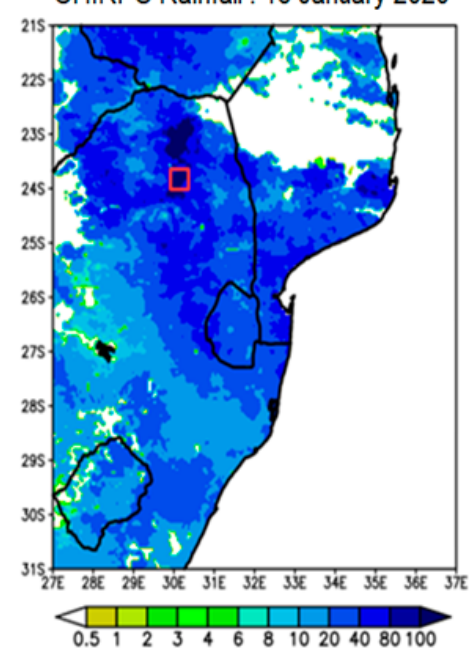

(b)

Figure 8. Daily CHIRPS rainfall during (a) 20 January 2013 and (b) 18 January 2020 over the study region. The location of the three communities in this study is shown in a red polygon.

The extreme rainfall of 18 January 2020 (Figure 8b) was associated with an upper air trough over the south of Botswana which allowed for an influx of moist tropical air into the study area. The upper trough developed ahead of a cut-off low-pressure system that affected the southwestern Cape of South Africa. Cut-off lows can occur throughout the year in South Africa, although with peaks during the austral autumn and spring seasons $[68,69]$. At the surface, a ridging anticyclone over the southeast coast of South Africa was driving moist and cold air from the Southern Ocean (not shown). The north eastern escarpment enhanced dynamical lifting resulting in heavy thunderstorms with rain over the study area. A combination of surface ridging anticyclones with disturbances in the upper air (such as a trough or a cut-off low) often results in severe weather and floods over South Africa, e.g., $[15,70-73]$.

\subsection{Mapping Flood Events}

Our analysis reveals that areas that have been flooded historically are presently still vulnerable and may become more vulnerable to future flooding (Figure 9). The location of these areas relative to the drainage channels reveals two different types of flooding. Flooding Case A is when there is flooding on the surface away from drainage channels caused by an indented surface without proper drainage and culverts (Figure 9). Case B represents flooding occurring along the drainage channels that can be assumed to have been caused either by extreme rainfall or blockage in the drainage channels.

Although some floods can be attributed to topography, land modification through land use and land cover changes can create blockages in the natural topographical drainage channels that may result in flooding [74]. Land modification also creates planar surfaces in naturally steep regions and this interferes with the runoff towards the drainage channels, thus resulting in floods [75]. During fieldwork, we found that several gravel roads in the study sites do not allow for rainwater to drain away from the road, resulting in stagnant water and ponding. 

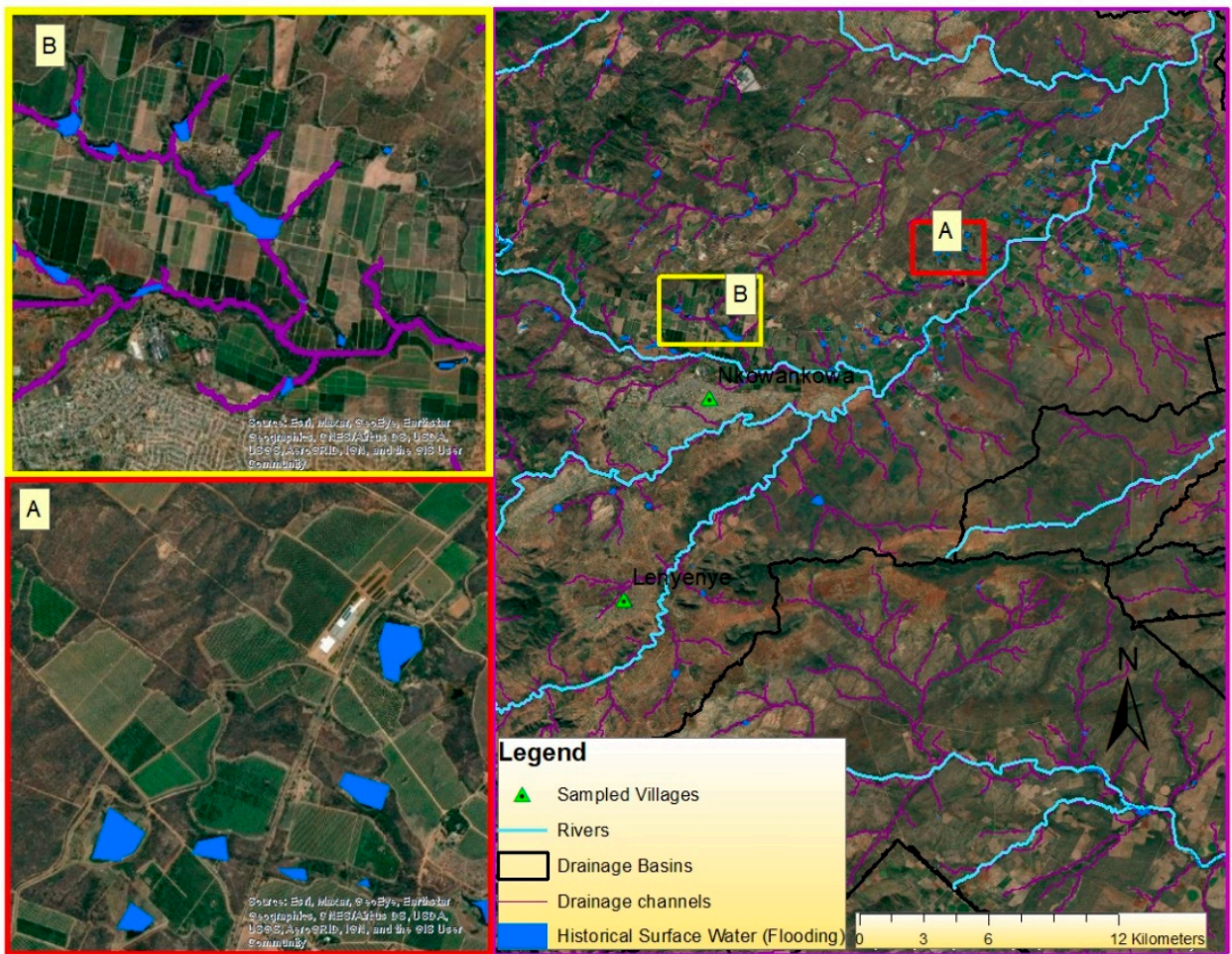

Figure 9. Close aerial view of sampled sites, showing different types of flooding cases in the Nkowankowa study area.

\subsection{Indicators of Flood Vulnerability}

In this section, we employed the FVI [42] to measure levels of flood vulnerability in three dimensions, namely social, economic and physical environment for each study site. Based on the surveys, Table 1 shows the important indicators, components and factors, and their function or relationship with flood vulnerability.

Table 1. Flood Vulnerability Index; selected indicators in Nkowankowa section B and C, Lenyenye and Ga-Kgapane Masakaneng [source: Field survey, 2016].

\begin{tabular}{|c|c|c|c|}
\hline Indicators & Components & Factors & $\begin{array}{c}\text { Function/Relationship with } \\
\text { Vulnerability }\end{array}$ \\
\hline $\begin{array}{l}\text { Frequency of Flood } \\
\text { Occurrence }\end{array}$ & Physical & Susceptibility & $\begin{array}{l}\text { Higher number of occurrences/year, } \\
\text { higher vulnerability }\end{array}$ \\
\hline Evaporation Rate & Physical & Susceptibility & Higher evaporation, lower vulnerability \\
\hline Unemployment & Economic & Susceptibility & Higher\%, higher vulnerability \\
\hline Dwelling quality & Economic & Susceptibility & $\begin{array}{l}\text { Poor quality (mud material), high } \\
\text { vulnerability }\end{array}$ \\
\hline $\begin{array}{l}\text { Infrastructure quality (e.g., } \\
\text { roads, storm drainage) }\end{array}$ & Economic & Susceptibility & $\begin{array}{c}\text { Higher } \% \text { of good quality infrastructure, } \\
\text { lower vulnerability }\end{array}$ \\
\hline Preparedness/Awareness & Social & Susceptibility & $\begin{array}{c}\text { Higher number of people aware, lower } \\
\text { vulnerability }\end{array}$ \\
\hline Education level & Social & Susceptibility & $\begin{array}{l}\text { Higher number of people uneducated, } \\
\text { higher vulnerability }\end{array}$ \\
\hline Disabled People & Social & Susceptibility & $\begin{array}{l}\text { Higher number of disabled, higher } \\
\text { vulnerability }\end{array}$ \\
\hline $\begin{array}{l}\text { Number of days with heavy } \\
\text { rainfall }\end{array}$ & Physical & Exposure & $\begin{array}{l}\text { Higher number of days, higher } \\
\text { vulnerability }\end{array}$ \\
\hline Topography & Physical & Exposure & $\begin{array}{l}\text { The flatter/low lying area of the slope, } \\
\text { higher vulnerability }\end{array}$ \\
\hline Household income & Economic & Exposure & $\begin{array}{l}\text { High household income, low } \\
\text { vulnerability }\end{array}$ \\
\hline
\end{tabular}


Table 1. Cont.

\begin{tabular}{|c|c|c|c|}
\hline Indicators & Components & Factors & $\begin{array}{c}\text { Function/Relationship with } \\
\text { Vulnerability }\end{array}$ \\
\hline Maintenance of Infrastructure & Economic & Exposure & High maintenance, lower vulnerability \\
\hline Population Density & Social & Exposure & $\begin{array}{c}\text { Higher number of people, higher } \\
\text { vulnerability }\end{array}$ \\
\hline Population Growth & Social & Exposure & $\begin{array}{l}\text { Fast population growth, higher } \\
\text { vulnerability. }\end{array}$ \\
\hline $\begin{array}{l}\text { Dam and storage } \\
\text { capacity/quality }\end{array}$ & Physical & Resilience & Higher capacity, lower vulnerability \\
\hline Floods Recovery Time & Physical & Resilience & High recovery time, less vulnerability \\
\hline Dam and storage capacity & Economic & Resilience & Higher capacity, lower vulnerability \\
\hline Economic Recovery & Economic & Resilience & $\begin{array}{l}\text { High economic recovery, less } \\
\text { vulnerability }\end{array}$ \\
\hline Response team & Economic & Resilience & $\begin{array}{c}\text { Effective response team, lower } \\
\text { vulnerability }\end{array}$ \\
\hline Early Warning System (EWS) & Social & Resilience & Having EWS reduces the vulnerability \\
\hline Emergency Service (ES) & Social & Resilience & Efficient ES, lower vulnerability \\
\hline Evacuation Route & Social & Resilience & $\begin{array}{l}\text { Better quality of roads, improve quality } \\
\text { evacuation }\end{array}$ \\
\hline Past experience (PE) & Social & Resilience & $\begin{array}{c}\text { Higher number of people with PE, lower } \\
\text { vulnerability. }\end{array}$ \\
\hline
\end{tabular}

Twenty-six indicators were selected in the three study sites; information about indicators was collected from the Mopani District Disaster Management Centre (MDDMC), Director of MDDMC, Greater Tzaneen Disaster Management Section, Greater Letaba Disaster Management Section, SAWS, household questionnaires and Census 2011. It was found that data or information about soil moisture and ground-water level indicators were mostly not available, and this is not unique to the study sites. These two indicators were unable to be included in the FVI computation regardless of their significance. The study employed the deductive approach, adopted from Balica [4] and Veenstra [76], which was supplemented by a preliminary field survey for relevancy of selected indicators. The following equations show the key variables considered for the physical, economic and social components of the FVI:

$$
\mathrm{FVI}_{\text {Physical }}=[\mathrm{FO}, \mathrm{Er}+\mathrm{H}, \mathrm{FH}, \mathrm{T}]-[\mathrm{DSC}, \mathrm{FRT}]
$$

where FO: Frequency of Flood Occurrence; Er: Evaporation Rate; H Rainfall: FH Number of days with Heavy Rainfall; T: Topography; DSC: Dam and Storage Capacity/quality; FRT: Floods Recovery Time.

$$
\text { FVI Economic }=[\mathrm{Um}, \mathrm{Dq}, \mathrm{Iq}+\mathrm{Hi}, \mathrm{Mi}]-[\mathrm{DSC}, \text { Ecor, Rt }]
$$

Um: Unemployment; Dq: Dwelling quality; Iq: Infrastructure quality; Hi: Household income; Mi: Maintenance of Infrastructure; DSC: Dam and Storage Capacity/quality; Ecor: Economic recovery; Rt: Response Team.

$$
\mathrm{FVI}_{\text {Social }}=[\mathrm{P} / \mathrm{A}, \mathrm{Ed}, \mathrm{Dp}+\mathrm{Pd}, \mathrm{Pg}]-[\mathrm{Ws}, \mathrm{Es}, \mathrm{Evr}, \mathrm{Pe}]
$$

P/A: Preparedness/Awareness; Ed: Education Level; Pd: Population Density; Pg: Population Growth; Ws: Early warning system; Es: Emergency service; Evr: Evacuation Route; Pe: Past Experience.

Table 2 shows that economically, Ga-Kgapane Masakaneng has a 'high vulnerability to floods' with FVI $=0.52$, whereas the physical dimension shows a 'small vulnerability to floods' with FVI $=0.20$ and the social component has a 'vulnerable to floods' level, $\mathrm{FVI}=0.27$. The economic component scored higher vulnerability than physical and social components in Ga-Kgapane Masakaneng, suggesting that flood vulnerability in the area is 
exacerbated by their economic state or characteristics. The study found that most household members in the area are unemployed and those employed generally earned low incomes. The Ga-Kgapane Masakaneng area exhibits a 'vulnerability to floods' level and may need to pay more attention to economic factors to mitigate flood vulnerability.

Table 2. Flood vulnerability levels in Ga-Kgapane Masakaneng [source: Field survey, 2016].

\begin{tabular}{ccc}
\hline \multicolumn{3}{c}{ Ga-Kgapane Masakaneng Flood Vulnerability } \\
\hline FVI Components & FVI Values & FVI Designation \\
\hline FVI Physical & 0.20 & Small vulnerability to floods \\
FVI Economic & 0.52 & High vulnerability to floods \\
FVI Social & 0.27 & Vulnerability to floods \\
FVI Total or General & 0.34 & Vulnerability to floods \\
\hline
\end{tabular}

Table 3 shows that, physically, Lenyenye has a 'small vulnerability to floods', FVI = 0.14 , whereas economically and socially, it has a 'vulnerability to floods' level. It was found that the social and economic components are worsening vulnerability to floods in Lenyenye village. More efforts are needed to focus on the socio-economy of this village to reduce and prevent floods, and their impacts. The overall level of flood vulnerability of Lenyenye shown in Table 3 is also 'vulnerability to floods' at FVI $=0.34$.

Table 3. Flood vulnerability levels in Lenyenye [source: Field survey, 2016].

\begin{tabular}{ccc}
\hline & Lenyenye Flood Vulnerability & \\
\hline FVI Components & FVI Values & FVI Designation \\
\hline FVI Physical & 0.14 & Small vulnerability to floods \\
FVI Economic & 0.38 & Vulnerability to floods \\
FVI Social & 0.40 & Vulnerability to floods \\
FVI Total or General & 0.34 & Vulnerability to floods \\
\hline
\end{tabular}

Table 4 shows flood vulnerability in Nkowankowa Section B and C and the index values indicate that economically and socially they are classified as 'vulnerability to floods'. Physically, the Nkowankowa settlements have higher vulnerability $(F V I=0.58)$ than both economic and social components, suggesting that topography has a more significant influence on the flood vulnerability in the area. The area is very flat and allows large amounts of flood waters to accumulate during heavy rain (Figure 3). Generally, the Nkowankowa area is 'vulnerable to floods' and more focus and attention are required on the physical component than on social and economic components of vulnerability. Flat or low-altitude locations exacerbate the vulnerability to floods because run-off from higher ground tends to accumulate in these low elevations [77].

Table 4. Flood vulnerability levels in Nkowankowa Section B and C [source: Field survey, 2016].

\begin{tabular}{ccc}
\hline \multicolumn{3}{c}{ Nkowankowa Section B and C Flood Vulnerability } \\
\hline FVI Components & FVI Values & FVI Designation \\
\hline FVI Physical & 0.58 & High vulnerability to floods \\
FVI Economic & 0.39 & Vulnerability to floods \\
FVI Social & 0.34 & Vulnerability to floods \\
FVI Total or General & 0.40 & Vulnerability to floods \\
\hline
\end{tabular}

Figure 10 provides a comparative analysis of flood vulnerability assessments between the three study sites. Nkowankowa Section $B$ and $C$ villages are generally more vulnerable $(\mathrm{FVI}=0.40)$ to floods than the other two study sites. Nkowankowa is dominated by physical component of vulnerability (due to its low altitude) which is higher than the other 
two locations. Ga-Kgapane Masakaneng exhibits higher vulnerability than the other two in the social component, whereas, economically, Lenyenye has the most vulnerability.

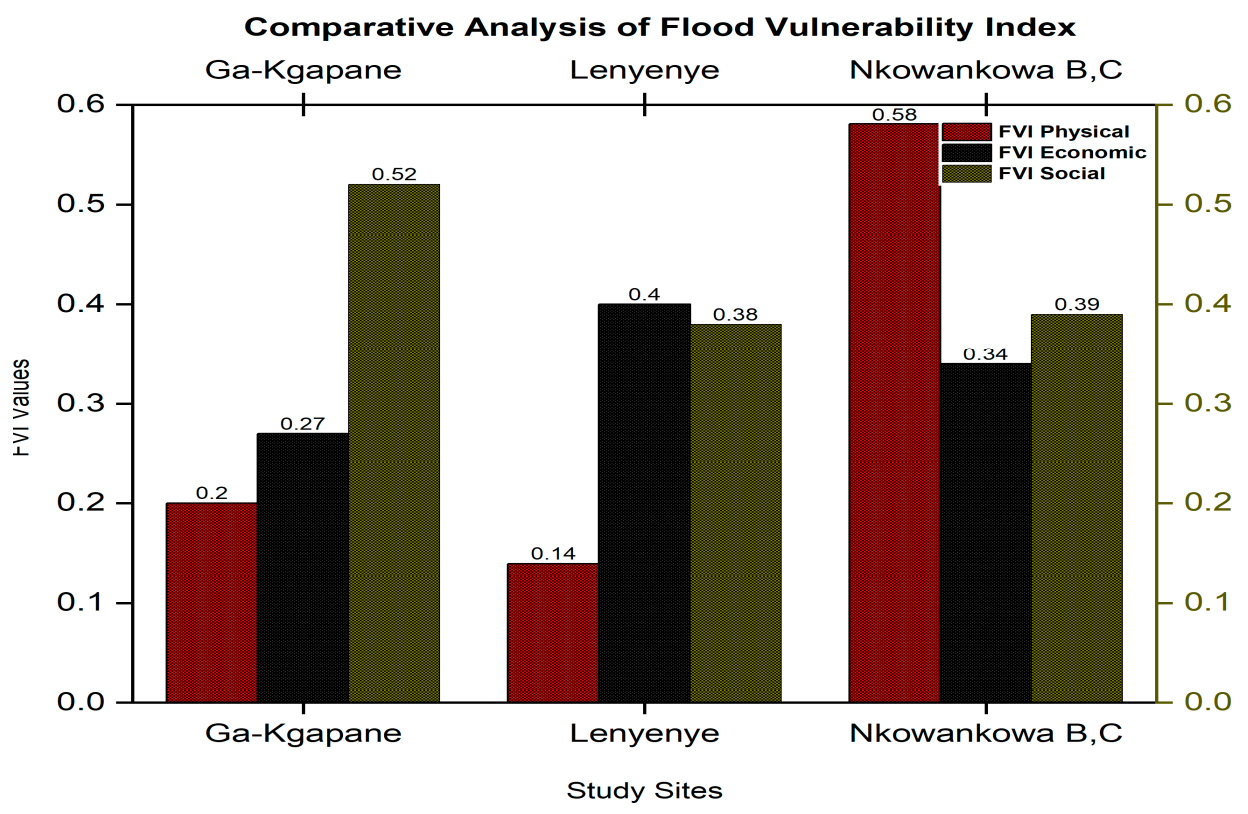

Figure 10. Comparative analysis of the FVI between the three study sites.

\subsection{Flood Adaptation Strategies and Actions}

The study found that floods have caused severe damages in all three study sites at Ga-Kgapane, Nkowankowa and Lenyenye in Mopani District. Households were seriously affected; as some of the houses were flooded, some individuals drowned, rivers spilled and overflowed, and certain roads were cut off or made impassable. The social survey, key informant interviews and field observations were the main instruments employed to identify flood adaptation strategies/actions in these areas. Households and key informants (government officials) were also asked to rank all identified coping strategies according to their preference and effectiveness.

We found that community adaptation strategies/actions were common across the sites at Ga-Kgapane Masakaneng, Lenyenye and Nkowankowa Section B and C (Figure 11). Most of the respondents preferred to make a 'Le-guba' (a raised porch surrounding a house), with shares of 30.5\% at Ga-Kgapane, $27.8 \%$ at Lenyenye and 23\% at Nkowankowa. Figure 12 shows the 'Le-guba' surrounding many houses across the study sites, suggesting that this long-term adaptation mechanism is popular with respondents. We also found that constructing a furrow around houses and culverts on roads was also popular, having a share of $\geq 22 \%$ at all three sites. Another common action involved use of sandbags made of burlap, polypropylene or sturdy materials containing sand and/or soil. Temporary relocation was also an option for severe cases of flooding, particularly in Lenyenye and Nkowankowa. Fewer respondents opted for the more permanent strategies/actions such as building protective walls around homes and terraces in the fields $(<10 \%)$. The least preferred options were building houses with stone and mortar and constructing a personal drainage system. 


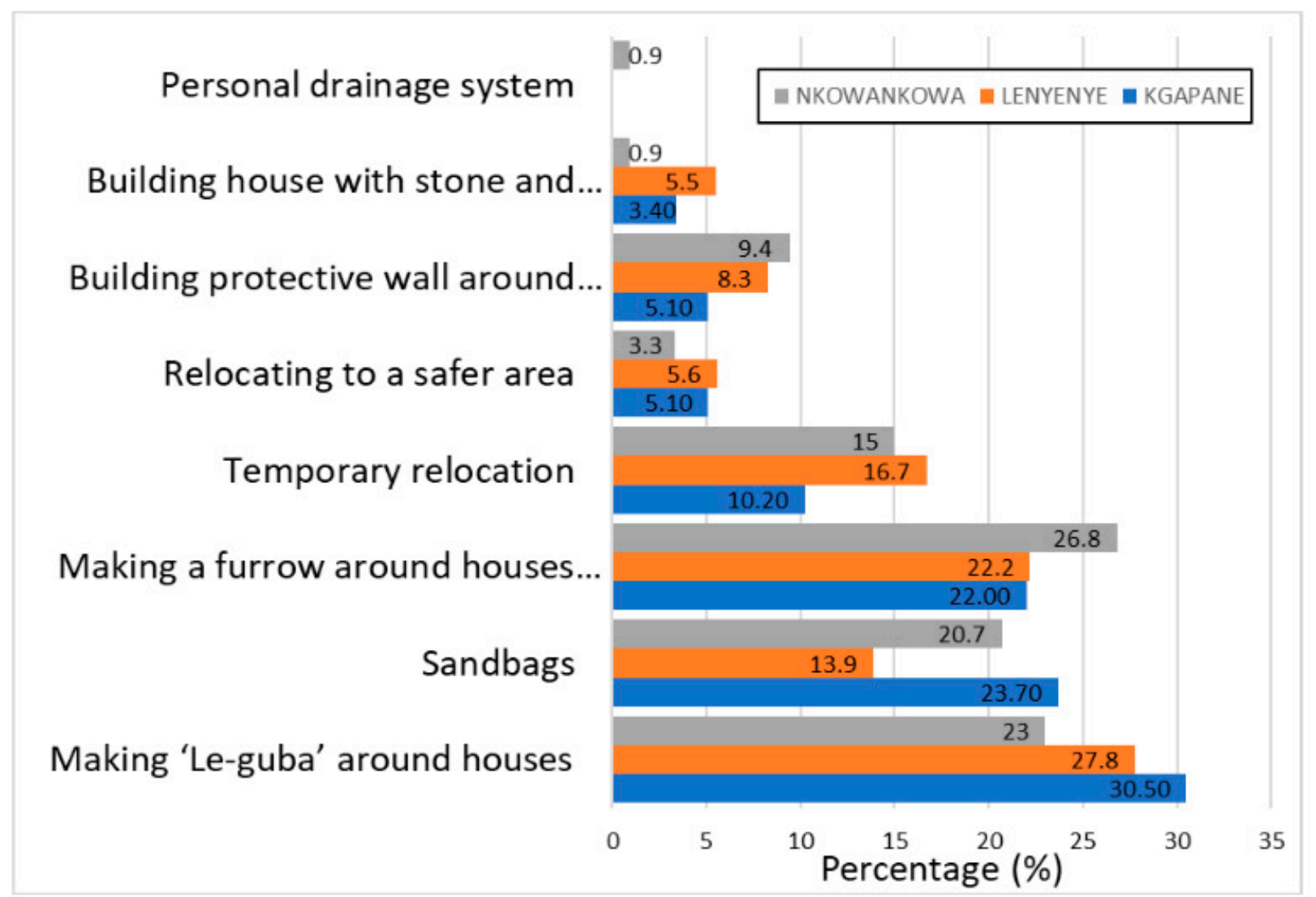

Figure 11. Household floods adaptation strategies in Nkowankowa, Lenyenye and Ga-Kgapane Masakaneng [source: Field survey, 2016].

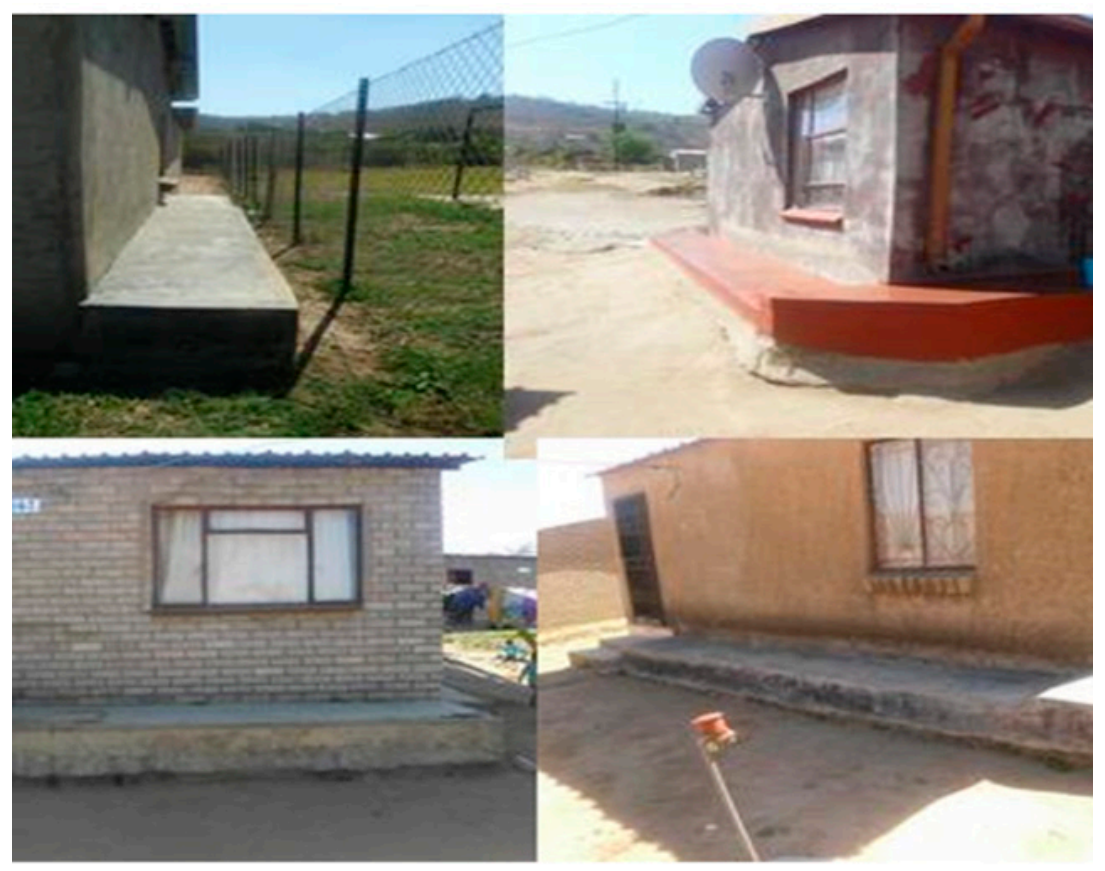

Figure 12. Several examples of a "Le-guba" on the stoep of houses in the study area [source: Field survey, 2016].

The road and storm water management authorities in Ga-Kgapane Masakaneng suggested that the best way to deal with floods in the area was to relocate people because 
the area was not meant for residential purposes and had previously been used as a dumping site. However, due to historical inequalities and high population growth, this would not be a simple task and, therefore, most respondents were not willing to relocate. The Acting Director of MDDMC, also a key informant, indicated that as the population was increasing, it was advisable to construct better drainage systems and houses to prevent further damage.

In support of low-income families, the South African government built low-cost houses across the country under the Reconstruction and Development Programme (RDP) of 1994 [78], and some were built in the study sites. In some cases, there were problems with the housing quality and also the location of the project. Many RDP houses had been damaged by flood waters (at the time of fieldwork) and households occupying them were at risk and 'vulnerable to floods'.

\section{Discussion}

This study focused on understanding the risk and vulnerability and adaptation to flood hazards among rural communities in Greater-Tzaneen and Greater Letaba municipalities in South Africa's northern Mopani District. We combined an analysis of vulnerability of the study sites to extreme rainfall and flooding, with physical, social and economic factors via a flood vulnerability index. In addition, resilience of a community is a key determinant of how vulnerable they may be, and this is particularly so in rural areas of South Africa; hence the focus of this study. We found that although extreme daily rainfall is rare, it occasionally occurs in this region, mainly during times of La Niña events when tropical storms and severe thunderstorms are more likely. Although there is a very small chance of tropical cyclones entering the Limpopo Province from the Mozambique Channel [49], when they do, they cause widespread extreme rainfall and floods in the study region. In addition, poor drainage, lack of culverts or blockages in drainage channels were the other factors that compounded flood vulnerability. A geo-spatial analysis using remote sensing data revealed two types of flooding caused either by extreme rainfall or by poor drainage or blocked drainage channels. Thus, analyzing all these factors plays a significant role in flood management and adaptation to prevent excessive damage and loss of lives and livelihoods in future.

From the field survey, we calculated the FVI [42] and found that the overall (social, economic and physical dimensions) level of flood vulnerability in the three rural settlements is 'vulnerability to floods'. This level is considered a medium-level vulnerability such that the area/community can recover from flood damage in months [47]. However, the individual components of the FVI reflected different contributors to vulnerability levels across the three sites. Nkowankowa Section B and C had a higher vulnerability than the other two locations in the physical component because of its flat terrain and poor drainage. It is also nearer to the escarpment where rainy days are more regular. Lenyenye had the higher vulnerability to floods in the economic dimension mainly due to its high unemployment or poor wages, whereas Ga-Kgapane Masakaneng was more vulnerable in the social dimension due to low education levels and lack of awareness/preparedness. By rank, Nkowankowa Section and C was more vulnerable to floods $(\mathrm{FVI}=0.40)$ than both Lenyenye $(\mathrm{FVI}=0.34)$ and Ga-Kgapane Masakaneng $(\mathrm{FVI}=0.34)$. Topography should be considered in Nkowankowa Section B and C during planning for the construction of future infrastructure, buildings and other development activities, as plain or flat slope areas are very prone to floods, whereas high elevations areas are free from floods but not flooding [79]. Well-drained gravel roads can also mitigate ponding or flooding on roads, often disrupting movements of people for social and economic activities.

Vulnerability studies can be complicated. Vulnerability is a concept that is incomplete without assessing the capacity of individuals to resist the impacts of floods [42]. There is a strong link between the components of vulnerability, as they do not operate or function independently of each other. The best means of conducting a comprehensive vulnerability study is by including all these components. Individuals can have a similar socio-economic status and physical exposure but employ different coping/adaptation strategies. Although 
this study dealt with historical and present-day flood vulnerabilities in Mopani District, projections of future vulnerabilities under climate change are even more important. Moreover, focusing on regional sensitivity, adaptive capacity and local exposure is critical in understanding local vulnerabilities and flood-related impacts [80]. This helps the policy and decision makers, and civil protection and disaster managers, to know exactly where to concentrate and invest to deal with risk and hazards.

Relevant and affordable adaptation strategies/actions are required to match the vulnerability levels of each area and its components. In addition, impacts of floods experienced over a region may influence local adaptation choices [81] with rural communities having high exposure, risk and minimal ability to recover. We found that the three study sites employed a variety of common adaptation strategies/actions to deal with the flood problem. Some strategies were more long-term, such as constructing a 'Le-guba', whereas others were short-term, such as temporary relocation, perhaps to higher ground. Issues of poor siting and quality of RDP houses, historical inequalities and population growth compound flood management in the region.

As the risk from floods increases, there is an urgent need to improve methods in decision support systems towards an effective early warning system, e.g., [48]. Accurate weather forecasts of extreme precipitation are crucial, while ensuring that weather warnings reach rural communities in a timely manner in order to protect lives, livelihoods and property. Another way to reduce risk is through implementation of a raft of improved and sustainable infrastructure maintenance regimes, with future developments focused on areas less prone to flooding [15].

There is a paucity of vulnerability assessments of rural settlements, such as those in Mopani District, where community livelihoods depend on natural resources and rain-fed subsistence agriculture, compounding their vulnerability compared to urban settlements. Despite being focused on the local scale, the findings of this study contribute to understanding the various factors that may affect vulnerability of similar rural communities to flood hazards. This is in addition to historical challenges such as lack of water supply infrastructure and good roads.

\section{Conclusions}

Our study detailed indicators and levels of vulnerability to floods in selected villages in Mopani District and determined a medium-level vulnerability calculated via the FVI. Analysis of extreme rainfall, geospatial maps derived from satellite remote sensing and other factors via the FVI determined that the study communities are indeed vulnerable to floods. The social survey revealed that the sampled households employed various adaptation strategies/actions to deal with floods in rural Mopani District. Although floods affected all three study sites, households employed several temporary and long-term adaptation strategies/actions. It was also found that the adaptation strategies employed by the three communities were markedly similar with only minor differences.

Although flood events may not be prevented, their impact and damage may be mitigated by proactive strategies employed by both vulnerable communities and disaster management authorities A participatory approach to flood risk management has also been recommended in a nearby town (Thohoyandou) where communities lead the response instead of a using 'top-down' approach [3]. Future research can also investigate the role of indigenous knowledge and local knowledge in water adaptation, as suggested by Zvobgo et al. [82]. Although our study focused on only the three vulnerable communities of GaKgapane, Lenyenye and Nkowankowa in Mopani District, a bigger study that investigates flood vulnerabilities across the entire district is necessary. Local and traditional authorities in the district can also play an active role to discourage communities from settling on poorly drained lowlands.

Author Contributions: Conceptualization, R.B.M., H.C., A.M., T.P.M., N.G.X. and T.C.M.; methodology, R.B.M., H.C., J.C., A.M., T.P.M., N.G.X. and T.C.M.; software, T.P.M.; validation, R.B.M., H.C., A.M., T.P.M., N.G.X. and T.C.M.; formal analysis, R.B.M.; investigation, R.B.M., H.C., A.M., T.P.M., 
N.G.X. and T.C.M.; writing-original draft preparation, R.B.M., H.C., A.M., J.C., T.P.M., N.G.X. and T.C.M.; writing-review and editing, R.B.M., H.C., A.M., T.P.M., N.G.X. and T.C.M.; visualization, T.P.M. and T.C.M.; supervision, A.M. and H.C.; funding acquisition, R.B.M. All authors have read and agreed to the published version of the manuscript.

Funding: This research was funded by the NATIONAL RESEARCH FOUNDATION (NRF) of South Africa and the RESEARCH AND PUBLICATIONS COMMITTEE of the University of Venda.

Institutional Review Board Statement: The study was conducted according to the guidelines of the University of Venda, and approved by its Research Ethics Committee under Project No: SES/17/GGIS/03/2204) on 4 April 2016.

Acknowledgments: This work was originally conceptualized from the Masters research of RBM at the University of Venda. Some of the climate data analysed here were obtained from the interactive KNMI Climate Explorer https:/ / climexp.knmi.nl/start.cgi, accessed online 15 November 2021. The help of Nkanyiso Mbatha with the CHIRPS rainfall analysis is acknowledged.

Conflicts of Interest: The authors declare no conflict of interest.

\section{Appendix A}

Table A1. Household survey questions and items.

\begin{tabular}{|c|c|c|}
\hline Components & Indicators & \multirow{4}{*}{$\begin{array}{l}\text { Awareness questions } \\
\text { - } \quad \text { Flood risk awareness } \\
\text { - } \quad \text { Preparedness through early } \\
\text { warning systems } \\
\text { - } \quad \text { Attendance of disaster related } \\
\text { workshops } \\
\text { - Financial support after flood } \\
\text { events } \\
\text { Adaptation strategies and actions } \\
\text { questions } \\
\text { - open questions }\end{array}$} \\
\hline Social & $\begin{array}{ll}\text { - } & \text { Sex } \\
\text { - } & \text { Education } \\
\text { - } & \text { Age } \\
\text { - } & \text { Marital status } \\
\text { - } & \text { Number people in households } \\
\text { - } & \text { Cultural heritage } \\
\text { - } & \text { Health status after flood } \\
& \text { events } \\
\text { - } & \text { Places of shelter. }\end{array}$ & \\
\hline Economical & $\begin{array}{ll}\text { - } & \text { Employment status } \\
\text { - } & \text { Main source of household } \\
\text { income } & \text { Range of monthly income } \\
\text { - } & \text { Number of household } \\
\text { - } & \text { Avembers employed } \\
\text { - } & \text { month } \\
\text { Dwelling quality and } \\
\text { - } & \text { Snfrastructure quality } \\
\text { - } & \text { Flood insurance } \\
\text { - } & \text { Recovery from floods }\end{array}$ & \\
\hline Physical & $\begin{array}{ll}\text { - } & \text { Rainfall } \\
\text { - } & \text { Topography } \\
\text { - } & \text { Flood frequency }\end{array}$ & \\
\hline
\end{tabular}


Table A2. Key informants survey questions and items.

\begin{tabular}{ll}
\hline Target & Type of Items \\
\hline & - Drainage system capacity \\
- Recent flood events \\
- - Cocio-economic and environmental impacts \\
- Factors determining flood vulnerability \\
- Infrastructure damaged by floods \\
- Diseases affecting communities after floods \\
- Dam and storage capacity \\
- Nathorities \\
- Extent of flood vulnerability \\
- Assistance from government and key stakeholders \\
- Recommendations to reduce flood vulnerability \\
\end{tabular}

\section{References}

1. Douben, N. Characteristics of river floods and flooding: A global overview, 1985-2003. Irrig. Drain. 2006, 55, S9-S21. [CrossRef]

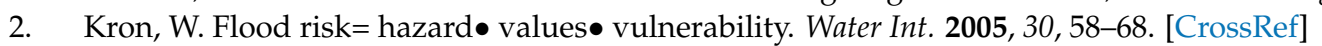

3. Sinthumule, N.I.; Mudau, N.I. Participatory approach to flood disaster management in Thohoyandou. Jàmbá J. Disaster Risk Stud. 2019, 11, 711. [CrossRef]

4. Balica, S. Applying the Flood Vulnerability Index as a Knowledge Base for Flood Risk Assessment; CRC Press, Taylor \& Francis Group: Leiden, The Netherlands, 2012.

5. Dilley, M. Natural Disaster Hotspots: A Global Risk Analysis; World Bank: Washington, DC, USA; Madrid, Spain,, 2005.

6. Kundzewicz, Z.W.; Mata, L.J.; Arnell, N.W.; Döll, P.; Kabat, P.; Jiménez, B.; Miller, K.A.; Oki, T.; Sen, Z.; Shiklomanov, I.A. Freshwater Resources and Their Management; Central Archive at the University of Reading: Reading, UK, 2007.

7. FloodList. More African Countries Aided by Servir Flood Modelling. 2015. Available online: http://floodlist.com/africa/page/7 (accessed on 26 November 2017).

8. Jakubcová, A.; Grežo, H.; Hrešková, A.; Petrovič, F. Impacts of flooding on the quality of life in rural regions of Southern Slovakia. Appl.Res. Qual. Life 2016, 11, 221-237. [CrossRef]

9. Connor, R.F.; Hiroki, K. Development of a method for assessing flood vulnerability. Water Sci. Technol. 2005, 51, 61-67. [CrossRef]

10. Rabalao, R.T. The Social, Psychological and Economic Impact of Flooding in Ga-Motla and Ga-Moeka Communities of Moretele District in North West Province, South Africa. Master's Thesis, Disaster Management Training and Education Centre for Africa, University of the Free State, Bloemfontein, South Africa, 2010.

11. Egbinola, C.N.; Olaniran, H.D.; Amanambu, A.C. Flood management in cities of developing countries: The example of Ibadan, Nigeria. J. Flood Risk Manag. 2017, 10, 546-554. [CrossRef]

12. Le Roux, A.; Van Huyssteen, E. SocioEconomic Landscape: The South African Socioeconomic and Settlement Landscape. In South Africa risk and Vulnerability Atlas; The South African National Department of Science and Technology, CPD Print: Pretoria, South Africa, 2010; pp. 15-21.

13. Zuma, B.D.; Luyt, C.D.; Chirenda, T.; Tandlich, R. Flood disaster management in South Africa. In Proceedings of the Legislative framework and current challenges', International conference on Applied Life Sciences (ICALS2012), Konya, Turkey, 10-12 September 2012.

14. Chakwizira, J. Rural transport and climate change in South Africa: Converting constraints into rural transport adaptation opportunities. Jàmbá J. Disaster Risk Stud. 2019, 11, 718. [CrossRef]

15. Chikoore, H.; Bopape, M.J.M.; Ndarana, T.; Muofhe, T.P.; Gijben, M.; Munyai, R.B.; Manyanya, T.C.; Maisha, R. Synoptic structure of a sub-daily extreme precipitation and flood event in Thohoyandou, north-eastern South Africa. Weather Clim. Extrem. 2021, 33, 100327. [CrossRef]

16. Rapolaki, R.S.; Blamey, R.C.; Hermes, J.C.; Reason, C.J. A classification of synoptic weather patterns linked to extreme rainfall over the Limpopo River Basin in southern Africa. Clim. Dyn. 2019, 53, 2265-2279. [CrossRef]

17. Chikoore, H.; Jury, M.R. South African drought, deconstructed. Weather Clim. Extrem. 2021, 33, 100334. [CrossRef]

18. Hart, N.; Reason, C.; Fauchereau, N. Cloud bands over southern Africa: Seasonality, contribution to rainfall variability and modulation by the MJO. Clim. Dyn. 2013, 41, 1199-1212. [CrossRef]

19. Engelbrecht, F.; Adegoke, J.; Bopape, M.J.; Naidoo, M.; Garland, R.; Thatcher, M.; McGregor, J.; Katzfey, J.; Werner, M.; Gatebe, C. Projections of rapidly rising surface temperatures over Africa under low mitigation. Environ. Res. Lett. 2015, 10, 085004. [CrossRef]

20. IPCC. Climate Change 2021: The Physical Science Basis. Contribution of Working Group I to the Sixth Assessment Report of the Intergovernmental Panel on Climate Change; Masson-Delmotte, V.P., Zhai, A., Pirani, S.L., Connors, C., Péan, S., Berger, N., Caud, Y., Chen, L., Goldfarb, M.I., Gomis, M., et al., Eds.; Cambridge University Press: Cambridge, UK, 2021; in press. 
21. Nembilwi, N.; Chikoore, H.; Kori, E.; Munyai, R.B.; Manyanya, T.C. The occurrence of drought in Mopani District Municipality, South Africa: Impacts, Vulnerability and Adaptation. Climate 2021, 9, 61. [CrossRef]

22. Lindesay, J.A. South African rainfall, the Southern Oscillation and a Southern Hemisphere semi-annual cycle. J. Climatol. 1988, 8, 17-30. [CrossRef]

23. Cook, K.H. A Southern Hemisphere wave response to ENSO with implications for southern Africa precipitation. J. Atmos. Sci. 2001, 58, 2146-2162. [CrossRef]

24. Reason, C.J.C.; Jagadheesha, D. A model investigation of recent ENSO impacts over southern Africa. Meteorol. Atmos. Phys. 2005, 89, 181-205. [CrossRef]

25. Driver, P.; Reason, C.J.C. Variability in the Botswana High and its relationships with rainfall and temperature characteristics over southern Africa. International. J. Climatol. 2017, 37, 570-581. [CrossRef]

26. Nicholson, S.E.; Selato, J.C. The influence of La Nina on African rainfall. Int. J. Climatol. 2000, 14, 1761-1776. [CrossRef]

27. Sahu, N.; Behera, S.K.; Yamashiki, Y.; Takara, K.; Yamagata, T. IOD and ENSO impacts on the extreme stream-flows of Citarium river in Indonesia. Clim. Dyn. 2012, 39, 1673-1680. [CrossRef]

28. Sahu, N.; Singh, R.B.; Kumar, P.; Da Silva, R.V.; Behera, S.K. La Niña impacts on austral summer extremely high-streamflow events of the Paranaiba River in Brazil. Hindawi 2013, 2013, 461693. [CrossRef]

29. Sahu, N.; Panda, A.; Nayak, S.; Saini, A.; Mishra, M.; Sayama, T.; Sahu, L.; Duan, W.; Avtar, R.; Behera, S. Impact of Indo-Pacific climate variability on high streamflow events in Malanadi River basin, India. Water 2020, 12, 1952. [CrossRef]

30. Khosa, E.; Kuonza, L.R.; Kruger, P.; Maimela, E. Towards the elimination of malaria in South Africa: A review of surveillance data in Mutale Municipality, Limpopo Province, 2005 to 2010. Malar. J. 2013, 12, 1-8. [CrossRef]

31. Braack, L.; Bornman, R.; Kruger, T.; Dahan-Moss, Y.; Gilbert, A.; Kaiser, M.; Oliver, S.V.; Cornel, A.J.; Lee, Y.; Norris, D.E.; et al. Malaria vectors and vector surveillance in Limpopo province (South Africa): 1927 to 2018. Int. J. Environ. Res. Public Health 2020, 17, 4125. [CrossRef] [PubMed]

32. Fitchett, J.M.; Hoongendoorn, G.; Swemmer, A.M. Economic costs of the 2012 floods on torism in the Mopani District Municipalicity. South Africa. Trans. R. Soc. S. Afr. 2016, 71, 187-194. [CrossRef]

33. Musyoki, A.; Thifhulufhelwi, R.; Murungweni, F.M. The impact of and responses to flooding in Thulamela Municipality, Limpopo Province, South Africa. JAMBA 2016, 8, 1-10.

34. Ntanganedzeni, B.; Nobert, J. Flood risk in Luvuvhu River, Limpopo Province, South Africa. Phys. Chem. Earth 2020, 124, 102959. [CrossRef]

35. Botai, C.M.; Botai, J.O.; Zwane, N.N.; Hayombe, P.; Wamiti, E.K.; Makgoale, T.; Murambadoro, M.D.; Adeola, A.M.; Ncongwane, K.P.; De Wit, J.P.; et al. Hydroclimatic extremes in the Limpopo River Basin, South Africa, under changing climate. Water 2020, 12, 3299. [CrossRef]

36. Molekoa, M.D.; Avtar, R.; Kumar, P.; Minh, H.T.; Dasgupta, R.; Johnson, B.; Sahu, N.; Verma, R.; Yunus, A. Spatio-Temporal Analysis of Surface Water Quality in Mokopane Area, Limpopo, South Africa. Water 2021, 13, 220. [CrossRef]

37. Kumar, D.; Battacharjya, R.B. Review of different methods and techniques used for flood vulnerabiliy analysis. Nat. Hazards Earth Syst. Sci. 2020, 1-30. [CrossRef]

38. Blaikie, P.; Cannon, T.; Davis, I.; Wisner, B. At Risk—Natural Hazards, People's Vulnerability and Disasters; Routledge: London, UK, 1994.

39. Green, C. The Evaluation of Vulnerability to Flooding, Disaster Prevention and Management, (13); Emerald Group Publishing Limited: Bingley, UK, 2004; pp. 323-329.

40. Gheorghe, A. (Ed.) Integrated Risk and Vulnerability Management Assisted by Decision Support Systems. In Relevance and Impact on Governance; Springer: Dordrecht, The Netherlands, 2005.

41. Merz, B.; Thieken, A.H.; Gocht, M. Flood risk mapping at the local scale: Concepts and challenges. In Flood risk management in Europe; Springer: Dordrecht, The Netherlands, 2007; pp. 231-251.

42. Balica, S.F.; Douben, N.; Wright, N.G. Flood vulnerability indices at varying spatial scales. Water Sci. Technol. J. 2009, 60, 2571-2580. [CrossRef]

43. Hufschmidt, G. A comparative analysis of several vulnerability concepts. Nat. Hazards 2011, 58, 621-643. [CrossRef]

44. Scheuer, S.; Haase, D.; Meyer, V. Exploring multicriteria flood vulnerability by integrating economic, social and ecological dimensions of flood risk and coping capacity: From a starting point view towards an end point view of vulnerability. Nat. Hazards 2011, 58, 731-751. [CrossRef]

45. Willroth, P.; Revilla Diez, J.; Aruntai, N. Modelling the economic vulnerability of households in the Phang-Nga Province (Thailand) to natural disasters. Nat. Hazards 2011, 58, 753-769. [CrossRef]

46. Fuchs, S.; Kuhlicke, C.; Meyer, V. Editorial for the special issue: Vulnerability to natural hazards-The challenge of integration. Nat. Hazards 2011, 58, 609-619. [CrossRef]

47. Balica, S.F.; Popescu, I.; Beevers, L.; Wright, N.G. Parametric and Physically Based Modelling Techniques for Flood Risk and Vulnerability Assessment: A Comparison; UNESCO-IHE: Delft, The Netherlands, 2012.

48. Balica, S.; Wright, N.G. Reducing the complexity of the flood vulnerability index. Environ. Hazards 2010, 9, 321-339. [CrossRef]

49. Reason, C.J.C.; Keibel, A. Tropical cyclone Eline and its unusual penetration and impacts over the southern African mainland. Weather Forecast. 2004, 19, 789-805. [CrossRef] 
50. Chikoore, H.; Vermeulen, J.H.; Jury, M.R. Tropical cyclones in the Mozambique Channel: January-March 2012. Nat. Hazards 2015, 77, 2081-2095. [CrossRef]

51. Department of Cooperative Governance and Traditional Affairs. Mopani District Disaster Management Centre Annual Risk Report; Government Printer: Tzaneen, South Africa, 2015.

52. Funk, C.; Peterson, P.; Landsfeld, M.; Pedreros, D.; Verdin, J.; Shukla, S.; Husak, G.; Rowland, J.; Harrison, L.; Hoell, A.; et al. The climate hazards infrared precipitation with stations-A new envi-ronmental record for monitoring extremes. Sci. Data 2015, 2, 1-21. [CrossRef]

53. Zhang, Y.; Jia, Y. Watershed Merging: A Simple and Effective Algorithm for Channel Network Identification and Extraction. Water Resour. Res. 2020, 56, e2019WR026943. [CrossRef]

54. Liu, X. Multi-Temporal Salton Sea Watershed Delineation: Land Use and Pollutants Input Analysis Using the Hydrology Tool in GIS. Ph.D. Thesis, UCLA, Los Angeles, CA, USA, 2020.

55. Theofanous, N.; Myronidis, D. A streamflow hydrograph analysis and simulation for a study case watershed. Int. J. Sustain. Agric. Manag. Inform. 2020, 6, 94-105. [CrossRef]

56. Wei, X.; Chang, N.B.; Bai, K.; Gao, W. Satellite remote sensing of aerosol optical depth: Advances, challenges, and perspectives. Crit. Rev. Environ. Sci. Technol. 2020, 50, 1640-1725. [CrossRef]

57. Anusha, N.; Bharathi, B. Flood detection and flood mapping using multi-temporal synthetic aperture radar and optical data. Egypt. J. Remote Sens. Space Sci. 2020, 23, 207-219. [CrossRef]

58. Statistics South Africa. General Household Survey 2011 [dataset]. Version 2. Pretoria. Statistics South Africa [Producer], 2011. Cape Town: DataFirst [distributor]. 2011. Available online: http://www.datafirst.uct.ac.za/dataportal/index.php/catalog/192 (accessed on 20 September 2015).

59. Ames, H.; Glenton, C.; Lewin, S. Purposive sampling in a qualitative evidence synthesis: A worked example from a synthesis on parental perceptions of vaccination communication. BMC Med. Res. Methodol. 2019, 19, 26. [CrossRef]

60. Lehohla, P. Census 2011: Population dynamics in South Africa; Statistics South Africa: Pretoria, South Africa, 2015 ; pp. 1-112.

61. Munyai, R.B.; Musyoki, A.; Nethengwe, N.S. An assessment of flood vulnerability and ad-aptation: A case study of HamutshaMuungamunwe village, Makhado municipality. Jàmbá J. Disaster Risk Stud. 2019, 11, 1-8. [CrossRef]

62. Balica, S.F.; Wright, N.G. A network of knowledge on applying an Indicator-based methodology for minimizing flood vulnerability. Hydrol. Process. 2009, 23, 2983-2986. [CrossRef]

63. Birkmann, J. Measuring vulnerability to promote disaster-resilient societies: Conceptual frame-works and definitions. Meas. Vulnerability Nat. Hazards 2006, 1, 9-54.

64. Gallopín, G.C. Linkages between vulnerability, resilience, and adaptive capacity. Glob. Environ. Chang. 2006, 16, $293-303$. [CrossRef]

65. Kendon, E.J.; Stratton, R.A.; Tucker, S.; Marsham, J.H.; Berthou, S.; Rowell, D.P.; Senior, C.A. Enhanced future changes in wet and dry extremes over Africa at convection-permitting scale. Nat. Commun. 2019, 10, 1-14. [CrossRef]

66. South African Weather Service. Annual Report 2012/2013; 2013; ISBN 978-0-621-41751-7. Available online: https: / / www.weathersa. co.za/Documents / AnnualReports/SAWS-Annual-Report-12-13.pdf (accessed on 29 November 2021).

67. Webster, E.M. A Synoptic Climatology of Continental Tropical Low Pressure Systems over Southern Africa and Their Contribution to Rainfall over South Africa. Master's Thesis, University of Pretoria, Pretoria, South Africa, 2019.

68. Singleton, A.T.; Reason, C.J.C. Variability in the characteristics of cut-off low pressure systems over subtropical southern Africa. Int. J. Climatol. A J. R. Meteorol. Soc. 2007, 27, 295-310. [CrossRef]

69. Ndarana, T.; Rammopo, T.S.; Chikoore, H.; Barnes, M.A.; Bopape, M.J. A quasi-geostrophic diagnosis of the zonal flow associated with cut-off lows over South Africa and surrounding oceans. Clim. Dyn. 2020, 55, 2631-2644. [CrossRef]

70. Crimp, S.J.; Mason, S.J. The extreme precipitation event of 11 to 16 February 1996 over South Africa. Meteorol. Atmos. Phys. 1999, 70, 29-42. [CrossRef]

71. Singleton, A.T.; Reason, C.J.C. A numerical model study of an intense cut-off low pressure system over South Africa. Mon. Weather Rev. 2007, 135, 1128-1150. [CrossRef]

72. Hart, N.C.G.; Reason, C.J.C.; Fauchereau, N. Tropical-extratropical interactions over southern Africa: Three cases of heavy summer season rainfall. Mon. Weather Rev. 2010, 138, 2608-2623. [CrossRef]

73. Muofhe, T.P.; Chikoore, H.; Bopape, M.M.; Nethengwe, N.S.; Ndarana, T.; Rambuwani, G.T. Forecasting intense cut-off lows in South Africa using the $4.4 \mathrm{~km}$ Unified Model. Climate 2020, 8, 129. [CrossRef]

74. Roy, P.; Pal, S.C.; Chakrabortty, R.; Chowdhuri, I.; Malik, S.; Das, B. Threats of climate and land use change on future flood susceptibility. J. Clean. Prod. 2020, 272, 122757. [CrossRef]

75. Hu, S.; Fan, Y.; Zhang, T. Assessing the effect of land use change on surface runoff in a rapidly urbanized city: A case study of the central area of Beijing. Land 2020, 9, 17. [CrossRef]

76. Veenstra, J. Flood vulnerability assessment on a commune level in Vietnam. Flood Vulnerability Assessment to Communes of the Ca River Basin in Nghe A Province in Vietnam. Bachelor's Thesis, University of Twente, Enschede, The Netherlands, 2013.

77. Ogbonna, C.E.; Ike, F.; Okwu-Delunzu, V.U. Spatial Assessment of Flood Vulnerability in Aba Urban Using Geographic Information System Technology and Rainfall Information. Int. J. Geosci. 2015, 6, 191-200. [CrossRef]

78. South African Government. Government Gazzette, Vol. 353, No. 16085. Cape Town. 1994. Available online: https://www.gov. $\mathrm{za} /$ sites / default/ files/governmentgazetteid16085.pdf (accessed on 15 November 2021). 
79. Kabenge, M.; Elaru, J.; Wang, H.; Li, F. Characterizing flood hazard risk in data-scarce are-as, using a remote sensing and GIS-based flood hazard index. Nat. Hazards 2017, 89, 1369-1387. [CrossRef]

80. Pathak, S.; Panta, H.K.; Bhandari, T.; Paudel, K.P. Flood vulnerability and its influencing factors. Nat. Hazards 2020, 104, 2175-2196. [CrossRef]

81. McElwee, P.; Nghiem, T.; Le, H.; Vu, H. Flood vulnerability among rural households in the Red River Delta of Vietnam: Implications for future climate change risk and adaptation. Nat. Hazards 2017, 86, 465-492. [CrossRef]

82. Zvobgo, L.; Johnston, P.; Williams, P.A.; Trison, C.H.; Simpson, N. The role of indigenous knowledge and local knowledge in water sector adaptation to cloimate change in Africa: A structured assessment. Available online: https://doi.org/10.21203/rs.3. rs-774241/v1 (accessed on 15 November 2021). 